\title{
Molecular Properties and Therapeutic Targeting of the EBV-Encoded Receptor BILF1
}

\author{
Julius Maximilian Knerr ${ }^{1}$, Thomas Nitschke Kledal ${ }^{2} \mathbb{D}$ and Mette Marie Rosenkilde ${ }^{1, *(D)}$ \\ 1 Laboratory for Molecular Pharmacology, Department of Biomedical Sciences, University of Copenhagen, \\ 2200 København, Denmark; julius.knerr@sund.ku.dk \\ 2 Synklino ApS, Rådhusvej 13, 2920 Charlottenlund, Denmark; tnk@synklino.com \\ * Correspondence: rosenkilde@sund.ku.dk; Tel.: +45-30604608
}

check for updates

Citation: Knerr, J.M.; Kledal, T.N.; Rosenkilde, M.M. Molecular Properties and Therapeutic Targeting of the EBV-Encoded Receptor BILF1. Cancers 2021, 13, 4079. https:// doi.org/10.3390/cancers13164079

Academic Editors: Lorenzo Leoncini and Lucia Mundo

Received: 15 July 2021

Accepted: 9 August 2021

Published: 13 August 2021

Publisher's Note: MDPI stays neutral with regard to jurisdictional claims in published maps and institutional affiliations.

Copyright: (C) 2021 by the authors. Licensee MDPI, Basel, Switzerland. This article is an open access article distributed under the terms and conditions of the Creative Commons Attribution (CC BY) license (https:/ / creativecommons.org/licenses/by/ $4.0 /)$.
Simple Summary: The Epstein-Barr virus (EBV) is a $\gamma$-herpesvirus residing in over $90 \%$ of adults worldwide. Besides causing a benign glandular fever (infectious mononucleosis), EBV is also associated with a wide range of different types of cancers. This review will present these malignancies, current therapies, and summarize the present knowledge on an EBV-encoded oncogenic protein called BILF1. As a member of class A G protein-coupled receptors that are intrinsically successful drug targets, BILF1 will be discussed for its potential as future target in EBV-associated diseases. Finally, ongoing development of novel EBV-specific therapeutics is briefly outlined.

\begin{abstract}
The $\gamma$-herpesvirus Epstein-Barr Virus (EBV) establishes lifelong infections in approximately $90 \%$ of adults worldwide. Up to 1,000,000 people yearly are estimated to suffer from health conditions attributed to the infection with this virus, such as nasopharyngeal and gastric carcinomas as well as several forms of B, T and NK cell lymphoma. To date, no EBV-specific therapeutic option has reached the market, greatly reducing the survival prognoses of affected patients. Similar to other herpesviruses, EBV encodes for a G protein-coupled receptor (GPCR), BILF1, affecting a multitude of cellular signaling pathways. BILF1 has been identified to promote immune evasion and tumorigenesis, effectively ensuring a life-long persistence of EBV in, and driving detrimental health conditions to its host. This review summarizes the epidemiology of EBV-associated malignancies, their current standard-of-care, EBV-specific therapeutics in development, GPCRs and their druggability, and most importantly consolidates the findings of over 15 years of research on BILF1 in the context of EBV-specific drug development. Taken together, BILF1 constitutes a promising target for the development of novel EBV-specific therapeutics.
\end{abstract}

Keywords: Epstein-Barr virus; cancer; oncogenic virus; G protein-coupled receptor; BILF1; constitutive activity; antiviral treatment

\section{Introduction}

This review on the Epstein-Barr virus (EBV) and its G protein-coupled receptor (GPCR) BILF1 coherently summarizes the knowledge gained within the last years of research. Considering the great impact of EBV on global health with up to 1,000,000 EBVassociated disease cases per year (Table 1), it is of great need to consolidate findings which could drive the development of novel EBV-specific treatments. Additionally, as GPCRs have proven to be highly druggable proteins [1], a significant effort has been put into elucidating the structure, function and druggability of virally encoded GPCRs. First discovered over 15 years ago [2,3], EBV-BILF1 has meanwhile been thoroughly investigated, leading to the revelation of its, among others, oncogenic and immunoevasive properties making it a potential drug target. 


\section{Epstein-Barr Virus}

The Epstein-Barr virus (EBV), also known as Human $\gamma$-herpesvirus 4, is a ubiquitous virus having infected over $90 \%$ of adults globally and forms part of the Lymphocryptovirus genus of the $\gamma$-herpesvirinae subfamily [4-6]. Discovered in Burkitt's lymphoma tissue in 1964, it is the first known oncogenic virus [7]. Its morphology is in line with other members of Herpesviridae, comprising a monopartite linear $\sim 172 \mathrm{~kb}$ dsDNA core encoding for around 100 proteins, a capsid, a tegument and an envelope holding a multitude of glycoproteins $[4,8]$. Similar to other herpesviruses, EBV has an active lytic and a dormant latent life cycle and thus causes a lifelong infection in the host, in which the virus can switch between latency and lytic reactivation [9]. Upon first contact, the virus enters epithelial cells by endocytosis and in a major histocompatibility complex II (MHC-II) independent (not expressed on epithelial cells) manner. First, the virus attaches to the complement component receptor CD21 with gp350/220 (also via BMRF-2 with integrins) and subsequently fuses with the membrane by the interaction of $\mathrm{gH} / \mathrm{gL}$ with epithelial integrins $\alpha \mathrm{v} \beta 5, \alpha \mathrm{v} \beta 6$ or $\alpha \mathrm{v} \beta 8$ [10] and gB [11]. After successful infection and dissemination from epithelial cells, EBV infects naïve B cells in the lymphoid tissue. These are infected through binding of the EBV glycoprotein gp350/220 to CD21, triggering endocytosis [12]. Then, EBV-gp42 in complex with gH/gL attaches to the MHC-II, which leads to membrane fusion of the host cell and the viral envelope via $\mathrm{gH} / \mathrm{gL}$ and $\mathrm{gB}$ [11].

The lytic infection, in which a host cell is hijacked to produce millions of new viruses, is crucial for the viral dissemination within the host and for transmission to a new host [13]. This cycle is driven by temporally regulated gene expression of immediate-early (IE), early (E) and late (L) lytic genes that encode for lytic proteins [13,14]. IE viral genes are the first genes to be expressed in the cycle and initiate the expression of $\mathrm{E}$ viral genes, as well as modulating the host cell environment. In EBV, BZLF1 and BRLF1 take over this role as transcription factors. Early genes are classified as being transcribed before viral replication and are subsequently essential for viral replication, as they, for instance, encode for the viral DNA polymerase (EBV-BALF5) [13]. Moreover, early proteins can also interfere with host cell processes such as major histocompatibility complex I (MHC-I) or MHC-II surface expression, effectively evading the host immune system and, hence, ensuring viral survival. In EBV, the three main early proteins interfering with MHC-I presentation are BNLF2a (inhibitor of transporter associated with antigen processing; TAP), BGLF5 (exonuclease degrading mRNA) and BILF1 (viral G protein-coupled receptor; vGPCR) [15-17], the latter of which is the main focus of this review. Proteins interfering with MHC-II surface-presentation are BGLF5, BZLF1 and gp42 [17]. Finally, the late lytic genes, for example, encode for structural proteins important for the assembly of new virions or envelope glycoproteins. They are expressed after the initiation of viral replication and can be inhibited by multiple factors preventing the replication of viral DNA. Examples are gp350/220 (viral entry into host cells), the three capsid proteins (BORF1, BDLF1, BcLF1), as well as MHC-I and MHC-II downregulating protein BDLF3 [18] and viral IL-10 homolog BCRF1 [14].

Besides the lytic cycle, EBV can undergo four different latency programs (0, I, II, III), each defined by a specific restricted expression profile of genes. Compared with the vast number of lytic genes, EBV latent genes are much smaller in number. These latent EBV gene products range from BamHI A region transcripts (BARTs) and microRNAs (miR-BART, miR-BHRF1) over noncoding EBER RNAs (EBER1, EBER2) to nuclear antigens (EBNA1, -2, $-3 \mathrm{~A},-3 \mathrm{~B},-3 \mathrm{C},-\mathrm{LP})$ and lastly membrane proteins (LMP1, $-2 \mathrm{~A},-2 \mathrm{~B})$ and are expressed during different latency programs (I-III) [19-21]. In latency 0 (in resting memory B cells), no viral genes are expressed. During cell division, EBV enters latency I, which is defined by sole expression of EBNA1, BART miRNAs and EBERs, to ensure replication and distribution of the viral genome (in the form of an episome) to the daughter cell. Additional expression of LMP1 and LMP2 initiates the latency II program. Expression of the full repertoire of latent genes indicates the latency program III [19]. In the host, persistent latency is generally established in resting memory B cells [19]. Entry to and dissemination from the host 
(lytic cycle) mainly goes through the mucosal epithelia, consistent with its main route of transmission through oral contact [9].

Predominantly in its latent stage, EBV has been shown to cause a variety of health conditions, which are outlined in the following chapter. While the previously covered definition of latency suggests strict lines between lytic and latent gene expression during latency, the expression of several lytic genes, including BILF1, has been detected in various latent cells (such as nasopharyngeal carcinoma tissue) [22]. This disruption of the traditional view on strict division of lytic and latent gene expression in EBV is extensively covered elsewhere [23].

\section{EBV Cancers and Standard of Care}

Primary infection with EBV, mostly during childhood or adolescence, is known to cause infectious mononucleosis (IM), a generally mild and self-containing glandular fever, in a minority of infected people [5]. More concerning, latent infections with EBV are connected to a large number of cancers in immunodeficient as well as in immunocompetent individuals. As mentioned above, EBV is the first identified oncogenic virus. It is linked to a plethora of health conditions; mostly cancers of B, T or NK cells (Burkitt's lymphoma (BL), Hodgkin's lymphoma (HL), post-transplant lymphoproliferative disorders (PTLD) and Mature T- and NK-cell neoplasms (MTNKL)/Peripheral T-cell Lymphoma (PTCL)) [5,24,25]. Some EBV-associated cancers are of epithelial (nasopharyngeal carcinoma (NPC), EBVassociated gastric carcinomas (EBVaGC), lymphoepithelioma-like carcinomas) and, very rarely, of mesenchymal (leiomyosarcoma) origin [5,24]. Moreover, a causative link between EBV and multiple sclerosis (MS) [26-28], systemic lupus erythematosus (SLE) [29-31] and breast cancer [32-35] is currently under investigation. Judging by global incidence, EBV-associated gastric carcinomas and nasopharyngeal carcinomas affect most people worldwide with both over 100,000 cases per year (Table 1). Furthermore, if a clear causality between EBV and breast carcinomas can be established, over 500,000 patients yearly could potentially be treated with more efficacious EBV-specific therapeutics (assuming an average of $26 \%$ prevalence of EBV in breast carcinomas [32]). Taken together, up to around 1,000,000 people worldwide are diagnosed with diseases with possible EBV involvement every year.

Figure 1 summarizes EBV-associated malignancies, while Table 1 covers these diseases in detail. It should be noted that the stated rates under 'Prognosis' (Table 1) mostly stem from single studies with a limited number of test subjects and not from meta-analyses of multiple studies. Hence, the given values inherently are not representative of every patient and are solely listed to provide a notion on the severity of the respective malignancies. Nonetheless, the OS and PFS found in the literature indicate great room for treatment improvement and immense potential to save lives. 


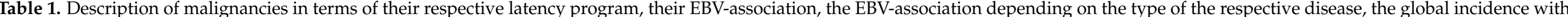

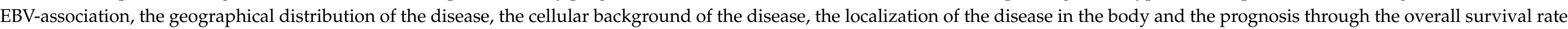
(OS), the progression free survival (PFS), the objective response rate (ORR) and complete remission rate (CRR) where applicable. Inspired by [36].

\begin{tabular}{|c|c|c|c|c|c|c|c|c|}
\hline & $\begin{array}{l}\text { EBV-Associated } \\
\text { Malignancy }\end{array}$ & EBV Association & $\begin{array}{l}\text { EBV Association-Dependent Upon } \\
\text { Type }\end{array}$ & $\begin{array}{l}\text { Incidence with EBV } \\
\text { Association }\end{array}$ & Geography & Cellular Background & Localization & Prognosis \\
\hline \multirow{9}{*}{ 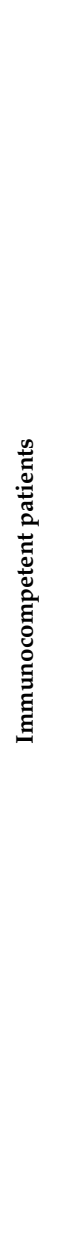 } & $\begin{array}{l}\text { Hodgkin lymphoma } \\
\text { (latency II) [37-41] }\end{array}$ & $\begin{array}{l}\text { Developed cnt: } \\
\text { 30-50\% } \\
\text { Developing cnt: } \\
\quad 80-90 \%\end{array}$ & $\begin{array}{l}\text { Mixed cellularity: } \\
\text { 60-80\% } \\
\text { Nodular sclerosis: } 20-40 \%\end{array}$ & $\begin{array}{l}29,000 / y[41] \\
\text { Up to } 56,500 \text { cases and } 20,500 \\
\text { deaths in } 2018^{*}[42]\end{array}$ & WW & $\begin{array}{c}\text { B cells } \\
\text { (Reed-Sternberg), } \\
\text { (T cells }<2 \%)\end{array}$ & $\begin{array}{l}\text { Nodal: } \\
\text { state } 1-3 \\
\text { Extranodal: } \\
\text { state } 4\end{array}$ & $\begin{array}{l}\text { CRR: } 80-90 \%[38] \\
15-20 \% \text { are } \\
\text { resistant/relapse }\end{array}$ \\
\hline & $\begin{array}{c}\text { Burkitt lymphoma } \\
\text { (latency I) } \\
{[7,37,41,43,44]}\end{array}$ & $\begin{array}{c}\text { Africa: } 85 \% \text {. USA: } \\
15 \%\end{array}$ & Endemic: $95 \%$, sporadic: $25 \%$. & $\begin{array}{c}7000 / \mathrm{y} \\
20 / 100,000 \text { children between } \\
5-9 \mathrm{y} \text { in sub-Saharan Africa } \\
{[41]}\end{array}$ & $\begin{array}{c}\text { Endemic: } \\
\text { Equa. Africa, New } \\
\text { Guinea; } \\
\text { Sporadic: WW HIV: WW }\end{array}$ & B cells & $\begin{array}{l}\text { Germinal centers, jaw } \\
\text { (young children), breast } \\
\text { and abdomen (older } \\
\text { children) }\end{array}$ & $\begin{array}{l}\text { Developed cnt: Overall } \\
\text { Cure > 90\% } \\
\text { 3y OS for } \\
\text { chemo-resistant: } 7 \% \\
\end{array}$ \\
\hline & $\begin{array}{l}\text { MTNKL/PTCL } \\
\text { (latency II) } \\
{[25,39,45-50]}\end{array}$ & $40-50 \%[49]$ & $\begin{array}{c}\text { AITL: >90\%, ANKL: > } 90 \% \text {, } \\
\text { ENKTCL-NT: 100\%, (PTCL-NOS): } \\
30 \% \text {, } \\
\text { SEBV+LOC: } 100 \% \text { [39] } \\
\text { 10-30\% of all NHL are } \\
\text { PTCL/MTNKL [48] }\end{array}$ & $\begin{array}{l}\text { Up to } 76,400 \text { cases and } 37,500 \\
\text { deaths in } 2018^{*}[48,49,51]\end{array}$ & $\begin{array}{l}\text { (East) Asia, America, } \\
\text { Europe, America }\end{array}$ & $\begin{array}{l}\text { NK cells, } \\
\text { T cells }\end{array}$ & $\begin{array}{l}\text { Systemic (AITL, ANKL, } \\
\text { SEBV+TLOC); midline } \\
\text { nasal/oral cavity, } \\
\text { pharynx } \\
\text { (ENKTCL-NT), }\end{array}$ & $\begin{array}{l}\text { ENKTCL: } 5 \text { y OS }<50 \% \text {. } \\
\text { ANKL: Med. OS time } \\
55 \text { days. } \\
\text { AITL: Med. 5y OS 32\%. } \\
\text { PTCL-NOS: Med.5y OS: } \\
\text { 20-30\% SEBV+LOC: } \\
\text { Death within few } \\
\text { weeks }\end{array}$ \\
\hline & $\begin{array}{c}\text { Lymphomatoid } \\
\text { granulomatosis } \\
\text { (latency I-II) [39,52-55] }\end{array}$ & $100 \%$ & & $\begin{array}{c}\text { Very rare } \\
\text { Prevalence unknown }\end{array}$ & Western countries & B cells & $\begin{array}{l}\text { Lungs, kidneys, skin, } \\
\text { CNS }\end{array}$ & $\begin{array}{c}5 y \text { OS rate: } 40 \% \\
50-60 \% \text { mortality rate }\end{array}$ \\
\hline & $\begin{array}{l}\text { NPC (latency II) } \\
{[41,56-59]}\end{array}$ & $95-100 \%$ & $\begin{array}{l}\text { Type 1: Squamous (low EBV assoc.) } \\
\text { Type 2: Non-keratinizing (high EBV } \\
\text { assoc.) } \\
\text { Type 3: Undifferentiated (high EBV } \\
\text { assoc.) } \\
\end{array}$ & $\begin{array}{c}78,000 / y, 80 / 100,000 \text { mean }> \\
40 \text { years old in Southern China } \\
{[41]} \\
\text { Up to } 129,000 \text { cases and } 73,000 \\
\text { deaths in } 2018^{*}[56,60]\end{array}$ & $\begin{array}{l}\text { Asia (Southern China), } \\
\text { Africa (north, northwest, } \\
\text { central west) }\end{array}$ & Epithelial cells & $\begin{array}{l}\text { Nasal/oral cavity, } \\
\text { pharynx }\end{array}$ & 3y OS 86\%, 5y OS 79\% \\
\hline & $\begin{array}{l}\text { Gastric carcinomas } \\
\text { (latency I) [41,61-65] }\end{array}$ & $9-10 \%$ & $\begin{array}{c}\text { Gastric lymphoepithelioma: } 90 \% \text {, } \\
\text { Moderately diff. adenocarcinomas: } \\
7 \%, \\
\text { Poorly diff. gastric adenocarcinomas: } \\
6 \%\end{array}$ & $\begin{array}{l}84,000 / y[41] \\
\text { Up to } 100,000 \text { cases and } 78,000 \\
\text { deaths in } 2018^{*}[65,66]\end{array}$ & WW, male predominance & $\begin{array}{l}\text { Epithelial cells (Gastric } \\
\text { pit cell) }\end{array}$ & Stomach & $\begin{array}{c}\text { Overall general GC: } \\
\text { median survival time < } \\
12 \text { months, } \\
\text { EBV+ 5y OS: } 71 \%\end{array}$ \\
\hline & $\begin{array}{l}\text { Lymphoepithelioma- } \\
\text { like carcinomas } \\
\text { (latency I ?) [67-74] }\end{array}$ & Varies & $\begin{array}{c}\text { Liver: rare } \\
\text { Stomach: }>80 \% \\
\text { Colon: rare } \\
\text { Salivary gland a: } 90 \% \\
\text { Lungs } \mathrm{a}^{\mathrm{a}}: 64 \% \\
\text { Thymus } \mathrm{a}: 44 \%\end{array}$ & Very rare & Mainly Asia & Epithelia & Varies & $\mathrm{N} / \mathrm{A}$ \\
\hline & $\begin{array}{c}\text { Colorectal carcinomas } \\
{[75]}\end{array}$ & Controversial & Controversial & Controversial & WW & Epithelia & Colon & N/A \\
\hline & $\begin{array}{l}\text { Breast carcinoma } \\
\text { (latency II) [32-35] }\end{array}$ & Controversial [32] & N/A & $\begin{array}{c}\text { Potentially } \\
\text { Up to 520,000 cases and } \\
162,500 \text { deaths in } 2018^{*}[32,76]\end{array}$ & $\begin{array}{l}\text { WW, highest EBV Assoc. } \\
\text { Asia and America }\end{array}$ & Mammary epithelia & Breast & $5 y$ OS > 90\% \\
\hline
\end{tabular}


Table 1. Cont.

\begin{tabular}{|c|c|c|c|c|c|c|c|c|}
\hline & $\begin{array}{l}\text { EBV-Associated } \\
\text { Malignancy }\end{array}$ & EBV Association & $\begin{array}{c}\text { EBV Association-Dependent Upon } \\
\text { Type }\end{array}$ & $\begin{array}{c}\text { Incidence with EBV } \\
\text { Association }\end{array}$ & Geography & Cellular Background & Localization & Prognosis \\
\hline & $\begin{array}{c}\text { Diffuse large B cell } \\
\text { lymphomas NOS } \\
\text { (DLBCL) (latency I-III) } \\
{[50,77-81]}\end{array}$ & $\sim 10 \%[79]$ & $30-40 \%$ of all NHL are DLBCL [78] & $\begin{array}{l}\text { Up to } 2000 \text { cases in } 2018 \text { * } \\
{[51,78,79]}\end{array}$ & $\begin{array}{c}\text { WW, } 10-15 \% \text { developing } \\
\text { cnt. } \\
5 \% \text { developed cnt. }\end{array}$ & B cells & $\begin{array}{l}\text { Nodal, extranodal } \\
\text { (lungs, gastrointestinal } \\
\text { tract) }\end{array}$ & $\begin{array}{c}\text { EBV+ DLBCL: } 5 y \text { OS } \\
25-54 \% .\end{array}$ \\
\hline \multirow{2}{*}{ 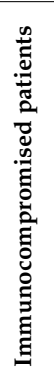 } & $\begin{array}{l}\text { Lymphomas (latency } \\
\text { I-III) }[39,77,82-99]\end{array}$ & $\begin{array}{c}\text { PTLD: } \\
\text { 50-80\% [92] } \\
\text { HIV: } 40-50 \% \\
{[39,88]}\end{array}$ & $\begin{array}{c}\text { Hodgkin (HIV): } 100 \% \\
\text { DLBCL (HIV): } 30-90 \%, \\
\text { Burkitt (HIV): } 50-60 \%, \\
\text { PbL (HIV): } 80 \% \\
\text { PbL (PTLD): } 30 \% \\
\text { PTLD in transplant patients: SOT: } \\
\text { 1-20\%, } \\
\text { HSCT: <2\% [92] }\end{array}$ & $\begin{array}{l}\text { PTLD: up to } 24,640 \text { in } 2019 * * \\
\text { [91,92]. HIV: up to } 60,000 \text { of } \\
\text { newly HIV infected in } 2020 \\
\text { will develop EBV+ lymphoma } \\
* * * \text { [89]; } 1-6 \% \text { of HIV+ patients } \\
\text { develop lymphomas each year } \\
\text { [90], } 50 \% \text { are EBV+ [88] }\end{array}$ & WW & $\begin{array}{l}\text { B cells }(90 \%) \\
\text { T cells } \\
\text { (seldom), }\end{array}$ & $\begin{array}{l}\text { Extranodal, CNS, } \\
\text { gastrointestinal }\end{array}$ & $\begin{array}{c}\text { Highly variable (see } \\
\text { Table 2) PTLD; } 2 \text { y OS } \\
83 \%\end{array}$ \\
\hline & $\begin{array}{l}\text { Leiomyosarcomas/smooth } \\
\text { muscle tumors (latency } \\
\text { I-III) [100-104] }\end{array}$ & $\begin{array}{c}\text { HIV: } 85 \% \\
\text { PT: } 98 \% \text { (B cell > } \\
90 \%, \\
\text { T cell > 70\%) } \\
\text { CI: } 100 \%[101]\end{array}$ & $\begin{array}{l}\text { HIV, PT, CI: Tumor manifestation in } \\
<1-5 \% \text { of each group [101] }\end{array}$ & & wW & Smooth muscle cells & $\begin{array}{l}\text { CNS, gut/liver, skin, } \\
\text { lungs, larynx, pharynx, } \\
\text { adrenal glands, spleen }\end{array}$ & $2 \mathrm{y}$ OS $66 \%, 5 \mathrm{y}$ OS $50 \%$ \\
\hline
\end{tabular}

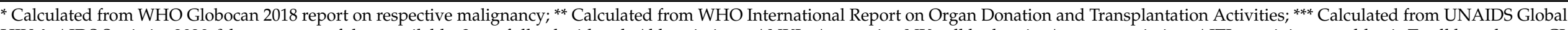

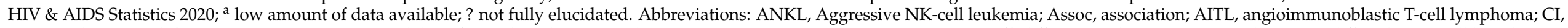

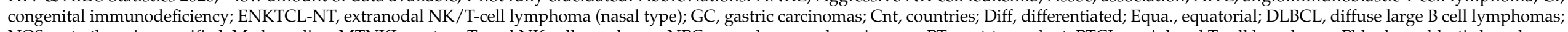

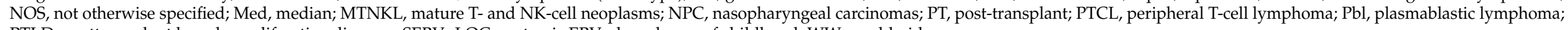
PTLD, posttransplant lymphoproliferative diseases; SEBV+LOC, systemic EBV+ lymphoma of childhood; WW, worldwide. 
Table 2 complements this summary by providing an overview of the current standard of care (SOC) for these diseases. Currently in surgery, solid organ transplants (SOT), antiviral therapeutics (highly active antiretroviral therapy (HAART), combined antiretroviral therapy (cART), chemotherapy (etoposide, prednisolone, oncovin, cyclophosphamide and hydroxydaunorubicin (EPOCH); cyclophosphamide, hydroxydaunorubicin, oncovin, prednisone $(\mathrm{CHOP}))$ and radiation therapy regimens and a combination of these are the most common approaches. At present, more promising treatments through immunotherapy are gaining traction, i.e., adoptive $\mathrm{T}$ cell therapy (ACT), checkpoint inhibiting (CPI) monoclonal antibodies (mAbs) and hematopoietic/autologous stem cell transplants (H/A-SCT) -also in combination with traditional methods. Among many others (cancers, as seen in both tables), one of these newer immunotherapeutical treatments has been examined for multiple sclerosis. Despite lacking a clear causality between EBV and MS, a recent study on EBV-specific T cell therapy in patients with progressive multiple sclerosis resulted in significant clinical improvement and thus could open the door for a wider adoption of alternative therapeutical approaches for MS [105].

Table 2. Current standard of care (SOC) including prognosis for EBV-associated diseases. For abbreviations, see Table 1.

\begin{tabular}{|c|c|c|c|}
\hline & $\begin{array}{l}\text { EBV-Associated } \\
\text { Malignancy }\end{array}$ & Treatment & Prognosis \\
\hline \multirow{13}{*}{ 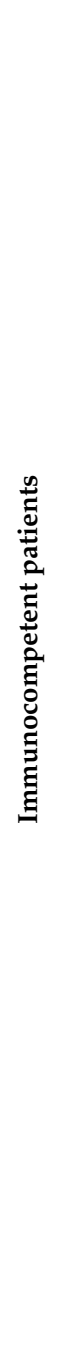 } & $\begin{array}{l}\text { Hodgkin lymphoma } \\
\text { (latency II) [37-41] }\end{array}$ & $\begin{array}{l}\text { Chemotherapy, radiation therapy, stem } \\
\text { cell transplant }\end{array}$ & $\begin{array}{c}\text { CCRR: } 80-90 \% \\
\text { Resistant/relapse: } 15-20 \%\end{array}$ \\
\hline & \multirow{2}{*}{$\begin{array}{l}\text { Burkitt lymphoma (latency } \\
\text { I) }[7,37,41,43,44,106-109]\end{array}$} & Multiple drug chemotherapy & $\begin{array}{l}\text { Overall cure rate in dev. Countries }>90 \% \text {, worse in } \\
\text { low-income. 3y OS is } 7 \% \text { for chemoresistant patients }\end{array}$ \\
\hline & & $\begin{array}{l}\text { Combined chemotherapy and } \\
\text { immunotherapy (rituximab, } \alpha \text {-CD20) }\end{array}$ & $\begin{array}{c}100 \% \text { overall survival and } 95 \% \text { progression-free survival at } 86 \\
\text { months. 3y OS: } 89 \%, 2 \text { y OS: } 82 \%\end{array}$ \\
\hline & \multirow{5}{*}{$\begin{array}{l}\text { Mature T- and NK-cell } \\
\text { neoplasms/Peripheral } \\
\text { T-cell Lymphoma (latency } \\
\text { II) }[25,39,45-50]\end{array}$} & $\begin{array}{l}\text { ENKTCL-NT: Chemotherapy, } \\
\text { radiotherapy }\end{array}$ & $\begin{array}{c}\text { General: } 5 \text { y OS }<50 \% \text {. Stage } 1 \text { and } 2 \text { diseases: } 5 \text { y PFS } 70-72 \% \text {; } \\
\text { 5y OS } 61-63 \% \text {. Stage } 1-2: \text { CRR } 87 \% \text {; } 5 \text { y OS } 73 \% \text {. Stage 3-4: } \\
\text { CRR } 45 \%, 5 y \text { OS } 47 \% \\
\text { 1y PFS } 80 \% \text {; advances stages: } 5 \text { y OS } 24 \% \text {, PFS } 16 \%\end{array}$ \\
\hline & & ANKL: chemotherapy, HSCT & $\begin{array}{l}\text { Median OS: } 55 \text { days. } 1 \text { y OS: } 4.4 \% \text {. Up to median OS } 300 \text { days } \\
\text { with allo-HSCT and } 43 \% 2 \text { y OS ("subacute ANKL") }\end{array}$ \\
\hline & & $\begin{array}{c}\text { AITL: chemotherapy (CHOP), } \\
\text { immunotherapy (CHOP + } \\
\text { rituximab/alemtuzumab), high-dose } \\
\text { therapy and autologous stem cell rescue } \\
\text { (HDT-ASCR) }\end{array}$ & $\begin{array}{c}\text { AITL: Median 5y OS 32\% } \\
\text { IT(Rituximab)+SCT: ORR } 80 \% \text {, CRR } 44 \%, 2 \text { y OS } 62 \% \\
\text { IT(azmab)+SCT: ORR 66-100\%, CRR } 13-65 \%, 2 \text { y OS }<50 \% \\
\text { HDT-ASCR: 5y OS } 52 \%\end{array}$ \\
\hline & & $\begin{array}{c}\text { PTCL-NOS: chemotherapy, HDT-ASCT, } \\
\text { no established SOC for relapse/refractory } \\
\text { patients }\end{array}$ & $\begin{array}{c}\text { PTCL-NOS: Median 5y OS: 20-30\% (<50\% with ASCT) } \\
\text { ORR: 50-60\%, CRR: } 20-30 \%\end{array}$ \\
\hline & & $\begin{array}{l}\text { Systemic EBV-positive T-cell lymphoma of } \\
\text { childhood: chemotherapy, HSCT }\end{array}$ & SEBV+TLOC: death within days or weeks of diagnosis \\
\hline & \multirow{2}{*}{$\begin{array}{c}\text { Lymphomatoid } \\
\text { granulomatosis (latency I-II) } \\
{[39,52-55]}\end{array}$} & $\begin{array}{l}\text { SOC: corticosteroids, chemotherapy, } \\
\text { IFN- } \alpha \text {, immunotherapy (rituximab) }\end{array}$ & $\begin{array}{c}\text { 5y OS: 40\% (SOC), Grade I-II: PFS 5y 56\%, Grade III: PFS 4y } \\
40 \% \text {, CRR 66\%, 50-60\% mortality rate }\end{array}$ \\
\hline & & $\begin{array}{l}\text { In trials: IFN- } \alpha \text { (p with CNS involment), } \\
\text { HSCT }\end{array}$ & $80-90 \%$ complete remission \\
\hline & \multirow[t]{3}{*}{$\begin{array}{c}\text { Nasopharyngeal } \\
\text { carcinomas (latency II) } \\
{[41,56-59]}\end{array}$} & $\begin{array}{l}\text { Surgery, chemotherapy, radiotherapy, } \\
\text { 1st line }\end{array}$ & $\begin{array}{c}\text { Phase } 2 \text { and } 3 \text { trials }(n=7) \text { comparing induction } \\
\text { chemotherapy and concurrent chemoradiotherapy vs. } \\
\text { concurrent chemoradiotherapy: } \\
\text { avg } 3 y(n=5) \text { OS } 86 \% \text { vs. } 75 \% \text { । PFS } 76 \% \text { vs. } 64 \% \\
\text { avg } 5 y(n=2) \text { OS } 79 \% \text { vs. } 73 \% \text { | PFS } 69 \% \text { vs. } 58 \%\end{array}$ \\
\hline & & $\begin{array}{l}\text { Immunotherapy (CPI: } \alpha \text {-PD1) in recurrent } \\
\text { or metastatic disease }\end{array}$ & $\begin{array}{c}\text { Phase } 1 / 2 \text { trials }(n=3): \text { avg ORR } 27 \% \text { I avg } 1 \mathrm{y} \text { OS }(n=2) \\
61 \% \text {, median } 16.8 \text { months I avg } 1 \mathrm{y} \text { PFS }(n=3) 26 \% \text {, median } 5 \\
\text { months }\end{array}$ \\
\hline & & CPI $\alpha$-PD1 with chemotherapy & Phase 1 trial: ORR 91\%, 1y PFS 61\% \\
\hline
\end{tabular}


Table 2. Cont.

\begin{tabular}{|c|c|c|c|}
\hline & $\begin{array}{l}\text { EBV-Associated } \\
\text { Malignancy }\end{array}$ & Treatment & Prognosis \\
\hline & \multirow{4}{*}{$\begin{array}{l}\text { Gastric carcinomas (latency } \\
\text { I) }[41,61-65]\end{array}$} & $\begin{array}{l}\text { General GC: surgical resection with } \\
\text { lymphadenectomy, radiotherapy, } \\
\text { chemotherapy } \\
\text { EBV+ possibly resistant to current } \\
\text { chemotherapy options (incl. docetaxel, } \\
\text { 5-Fluorouracil) }\end{array}$ & $\begin{array}{l}\text { Overall general GC: OS 20\%, median survival time }<12 \\
\text { months } \\
\text { Recurrence rates (EBV+GC, stages): } 0 \% \text { (I), 21\% (II), 33\% (III), } \\
83 \% \text { (IV) }\end{array}$ \\
\hline & & Immunotherapy (CPI: $\alpha$-PD1, $\alpha$-PDL1) & $\begin{array}{l}\text { 2nd-3rd line of treatment, phase II/III trials over } 100 \text { patients } \\
(n=2) \text { : avg ORR } 11.3 \% \text {, OS time } 5.43 \text { months (vs. placebo } 0 \% \text {, } \\
4.14 \text { months) } \\
\alpha \text {-PDL } 1 \text { vs. chemotherapy trial: } \\
\text { RR } 2.2 \% \text { vs. } 4.3 \% \text {, OS time } 4.6 \text { vs. } 5 \text { months }\end{array}$ \\
\hline & & $\begin{array}{l}\text { DNA methylation } \\
\text { inhibitors/Demethylating agents }\end{array}$ & $\begin{array}{c}\text { Phase I trial: Significant epigenetic and clinical responses of } \\
\text { epigenetic priming with 5-azacytidine (prior to } \\
\text { chemotherapy) in patients with locally advanced } \\
\text { esophageal/gastric adenocarcinoma }\end{array}$ \\
\hline & & PI3K inhibitors & $\begin{array}{c}\text { Phase III trial: no significant improvement in OS for } \\
\text { advanced GC of everlimos in 3rd line treatment } \\
\text { Phase I trial: prolonged stable disease with continuous } \\
\text { dosing of PX-866 }\end{array}$ \\
\hline & $\begin{array}{l}\text { Lymphoepithelioma-like } \\
\text { carcinomas (latency I ?) } \\
\text { [67-74] }\end{array}$ & Surgery, chemotherapy & Varies \\
\hline & $\begin{array}{l}\text { Breast carcinoma (latency II) } \\
\qquad[32-35]\end{array}$ & $\begin{array}{l}\text { Surgery, radiotherapy, chemotherapy, } \\
\text { immunotherapy }\end{array}$ & Generally 5y OS > 90\% \\
\hline & $\begin{array}{l}\text { EBV+ diffuse large B cell } \\
\text { lymphoma, NOS (latency } \\
\text { I-III) }[50,77-81]\end{array}$ & $\begin{array}{c}\text { Antiviral chemotherapy R-CHOP } \\
\text { immunotherapy rituximab, durvalumab, } \\
\text { nivolumab }(\alpha-\text {-CD20/PDL1/PD1) } \\
\text { EBV CTL, ASCT }\end{array}$ & $\begin{array}{c}\text { 5y OS } 25-54 \% \\
>45 \text { y/o: median survival } 2 \text { years } \\
<45 \text { y/o: } \text { CRR }>80 \%\end{array}$ \\
\hline & $\begin{array}{l}\text { Multiple sclerosis } \\
{[26-28,77,105,110-115]}\end{array}$ & $\begin{array}{l}\text { Immunotherapy, EBV-specific T-cell } \\
\text { immunotherapy in trials }\end{array}$ & $\begin{array}{c}\text { Life expectancy not greatly affected, irreversible disabilities } \\
\text { possible, } 90 \% \text { relapsing, remitting MS } \\
10 \% \text { progressive MS }[115]\end{array}$ \\
\hline \multirow{6}{*}{ 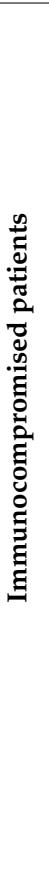 } & \multirow{5}{*}{$\begin{array}{l}\text { Lymphomas (latency I-III) } \\
\text { [39,77,82-99,106,109] }\end{array}$} & $\begin{array}{l}\text { Reduction/cessatation of immune } \\
\text { suppression (1st line) }\end{array}$ & PTLD: ORR 0-73\% (biggest study: CRR 37\%) \\
\hline & & Chemotherapy & $\begin{array}{c}\text { HIV: Burkitt's lymphoma HAART + chemotherapy: ORR } \\
\text { 70\%, 3y OS 52\% } \\
\text { HIV: Hodgkin's lymphoma cART + chemotherapies: avg 3y } \\
\text { OS 51\% I 5y OS 76\% } \\
\text { HIV: Burkitt lymphoma chemotherapy: 4y OS 72\% } \\
\text { PbL-HIV: median OS 6-19 months } \\
\text { PbL-PTLD: median OS } 7 \text { months }\end{array}$ \\
\hline & & $\begin{array}{l}\text { Immunotherapy (rituximab) }(+ \\
\text { chemotherapy) }\end{array}$ & $\begin{array}{r}\text { PTLD (SOT) chemotherapy + immunotherapy, age <30y }(n= \\
\text { 55): CRR 69\%, } 2 \text { y OS } 83 \% \\
\text { PTLD: Phase II trials rituximab: ORR } 55 \%, 25 \% \text { relapse } \\
\text { HIV: Hodgkin's lymphoma ASCT + high dose chemotherapy } \\
\text { (relapse): 32-month avg OS } 61 \% \\
\text { HIV: Burkitt's lymphoma EPOCH-R: } 90 \% \text { OS and } 100 \% \text { PFS } \\
\text { at } 86 \text { months } \\
\text { HIV: Burkitt's } 2 \text { y OS: } 73 \%\end{array}$ \\
\hline & & Cellular immunotherapy & $\begin{array}{c}\text { Phase II trial PTLD (HSCT, SOT) allogeneic EBV-specific CTL } \\
\text { by best HLA match: } 6 \text {-month ORR } 52 \%, 42 \% \text { CRR }\end{array}$ \\
\hline & & Transplantation (+ medication) & $\begin{array}{c}\text { HIV: Hodgkin's lymphoma ASCT + high dose chemotherapy } \\
\text { (relapse): 32-month avg OS } 61 \%\end{array}$ \\
\hline & $\begin{array}{l}\text { Leiomyosarcomas/smooth } \\
\text { muscle tumors (latency } \\
\text { I-III) [100-104] }\end{array}$ & $\begin{array}{l}\text { Chemotherapy, surgery, antiviral therapy, } \\
\text { reduced immunosuppression, adoptive } \\
\text { T-cell therapy }\end{array}$ & $\begin{array}{c}\text { PT-SMT: } 2 \text { y OS } 66 \% \text {, median of death post manifestation } 5.5 \\
\text { months } \\
\text { PT /HIV-SMT: } 5 y \text { OS } 50 \%\end{array}$ \\
\hline
\end{tabular}




\begin{tabular}{|c|c|}
\hline Immunocompetent & Immunocompromised \\
Hematological malignancies \\
Burkitt Lymphoma (BL) \\
Diffuse Large B Cell Lymphoma (DLBCL) \\
Hodgkin Lymphoma (HL) \\
Lymphomatoid Granulomatosis \\
T- and NK-cell Lymphoma (MTNKL/PTCL) \\
Epithelial malignancies \\
Gastric Carcinoma (GC) \\
Lymphoepithelioma-like Carcinoma \\
Nasopharyngeal Carcinoma (NPC) \\
Breast Carcinoma (controversial) \\
Other diseases
\end{tabular}

Figure 1. EBV-associated diseases in immunocompetent (left) and immunocompromised (right) patients. Details are provided in Table 1. Created with BioRender.com.

\section{G Protein-Coupled Receptors}

4.1. Basics

In the following, the basics on G protein-coupled receptors (GPCRs), also known as seven transmembrane receptors (7TM receptors), are outlined. GPCRs are an essential type of eukaryotic membrane proteins, importantly involved in signal transduction across the cell membrane. According to the International Union of Pharmacology (IUPHAR), GPCRs are divided into five main families: Rhodopsin-like (class A), Secretin (class B), Glutamate (class C), Frizzled/Taste (class F) and Adhesion GPCRs [116]. These receptors consist of an extracellular N-terminus, seven hydrophobic transmembrane helices, joined by three intracellular (ICL) and extracellular loops (ECL), and a cytosolic C-terminus. Class A receptors are the most thoroughly studied receptors and are the focus of this review. They contain a conserved disulfide bridge between transmembrane helix 3 (TM-3) and ECL-2 $[117,118]$, and display a highly conserved DRY-motif essential for signaling at the cytosolic end of TM-3 [118,119]. A schematic depiction of the Class A GPCR structure is presented in Figure 2A. Depending on the specific GPCR, the activating stimuli range from endogenous neurotransmitters, metabolites, hormones or chemokines (chemotactic cytokines) over natural exogenous stimuli such as ions, light and odors to synthetic stimuli 
such as specific medications $[1,117,120,121]$. In fact, around 34\% of all FDA-approved drugs act on GPCRs [1].

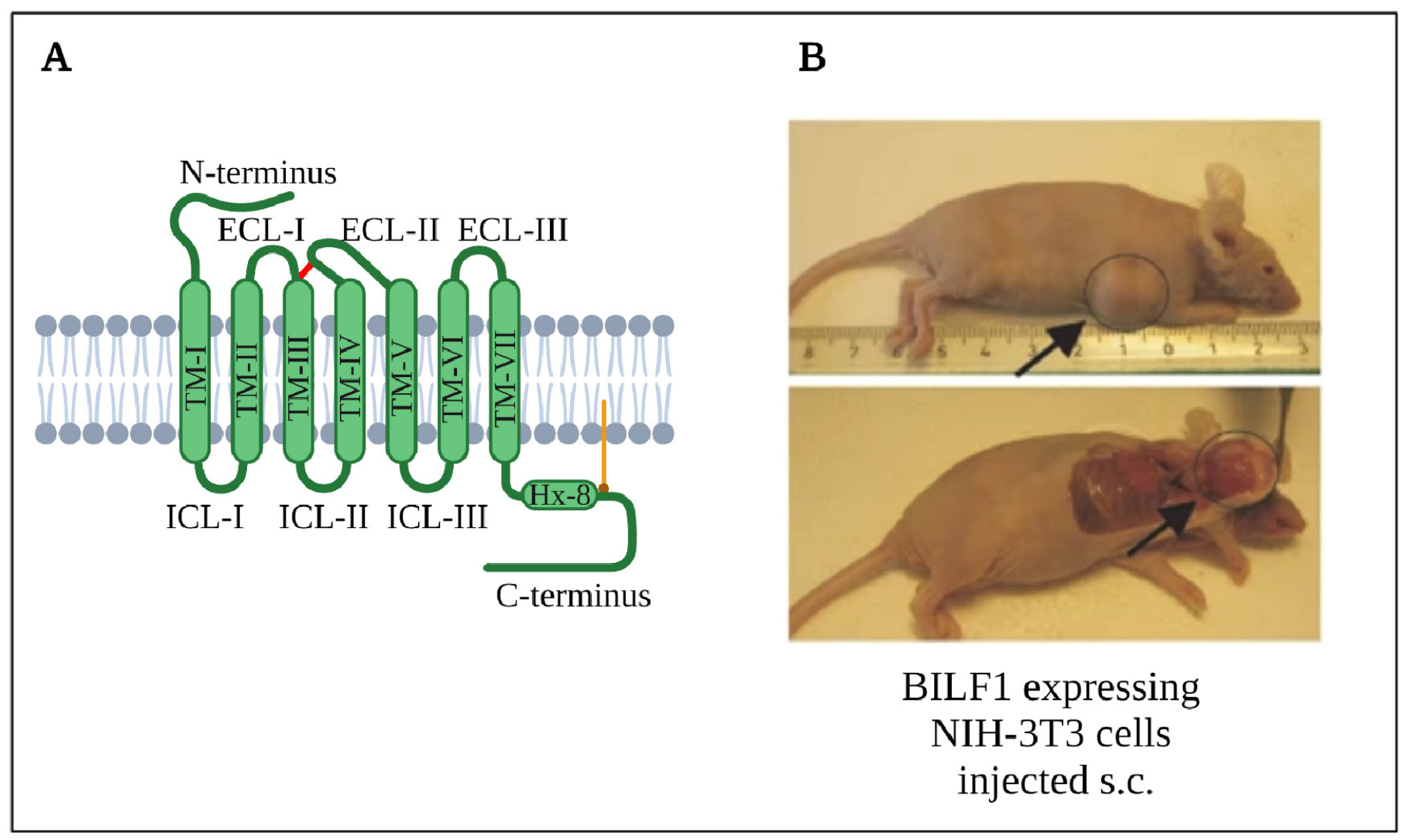

Figure 2. (A) Common structure of a class A G protein-coupled receptor (GPCR), such as BILF1. It shows the seven hydrophobic transmembrane (TM) helices, the linking intracellular (ICLs) and extracellular loops (ECLs), and a conserved disulfide bond (red) between TM-3 and ECL-2, Helix 8 and a palmitoylation in orange. (B) BILF1 expressing NIH-3T3 cells injected s.c. form tumors in a nude mouse model [122]. Created with BioRender.com.

While remaining in an equilibrium of active and inactive conformations in the absence of a ligand (basal or constitutive activity), a GPCR's active conformation can be stabilized through an agonistic ligand (increased activity to $100 \%$ for full agonists and less for partial agonists) $[117,120,121]$. This allows the GPCR to promote GTP for GDP exchange in the $G \alpha$ subunit of its cognate heterotrimeric $G$ protein, assembled by a $G \alpha, G \beta$ and $G \gamma$ subunits. Subsequently, the G protein is released from the GPCR and G $\alpha$ dissociates from the $G \beta \gamma$ dimer, in order to separately initiate amplified intracellular signaling cascades. On the contrary, inverse agonists push the active/inactive conformation equilibrium of the GPCR to the side of inactivation, resulting in a decreased activity compared with the baseline. Additionally, neutral antagonists block the agonist-binding pocket and thus retain basal activity of the receptor and inhibit activation or inactivation through other ligands. Finally, receptors that are active in absence of a ligand are considered constitutively active GPCRs [120,121].

For $G$ proteins, the class of $\alpha$ subunit determines its specificity toward downstream effectors, where $\mathrm{G} \alpha \mathrm{i}$ inhibits adenylyl cyclase, $\mathrm{G} \alpha$ s activates adenylate cyclase (triggering the cyclic adenosine monophosphate (cAMP)-dependent pathway), G $\alpha q$ activates phospholipases C (initiating inositol trisphosphate/diacylglycerol (IP3/DAG) pathway) and G $\alpha_{12 / 13}$, among others, interacting with Ras and Rho [123-125]. The G $\beta \gamma$ dimer is known to interact with phospholipases, receptor kinases and ion channels [121]. Finally, /GPCRs can recruit arrestins through phosphorylation of their C-terminus by $\mathrm{G}$ protein-coupled receptor kinases (GRKs). This inhibits $G$ protein signaling (desensitization), promotes internalization 
of the GPCRs by clathrin-vesicles and modulates G protein-independent downstream signaling networks $[117,121]$. Some ligands might initiate a $G$ protein response, while others are more biased toward generating an arrestin response [117].

The general concepts of GPCR signaling are depicted in Figure 3.

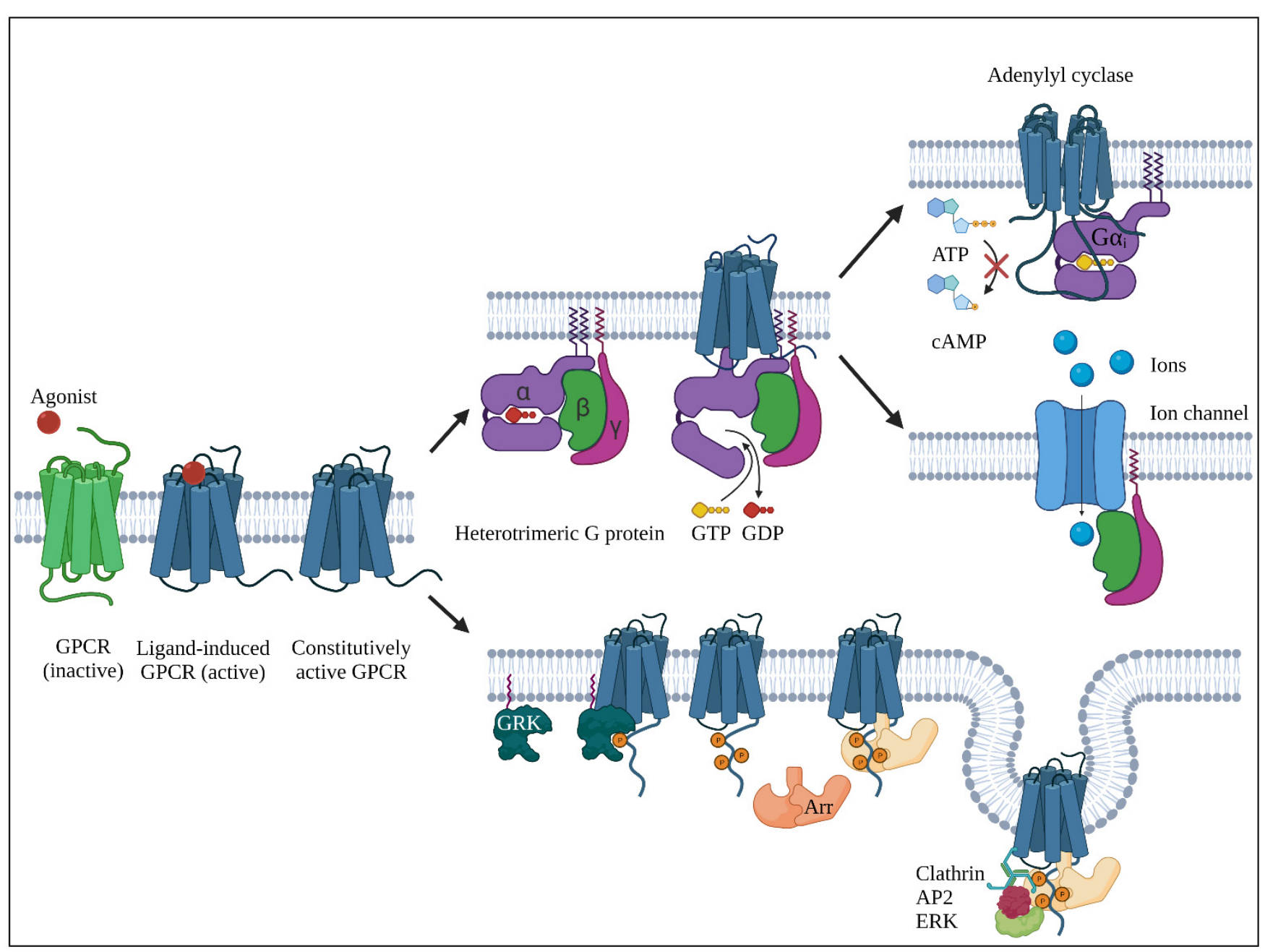

Figure 3. Summary of GPCR activity of constitutively active GPCRs or following binding of an agonist to a receptor. Top, the classical G protein pathway. GTP for GDP exchange in the G protein $\alpha$ subunit results in dissociation and modulation of downstream effectors such as G $\alpha$ i inhibition of adenylyl cyclase and G $\beta \gamma$ activation of ion channels. Bottom, arrestinassociated signaling via activated GPCRs. Phosphorylation of the cytosolic C-terminus by a G protein-coupled receptor kinase (GRK) leads to arrestin (Arr) recruitment and activation. This promotes receptor endocytosis via interactions with the clathrin adaptor protein 2 (AP2) complex and activation of extracellular signal-regulated kinase (ERK). Created with BioRender.com. Inspired by Weis et al. [117] and Komolov et al. [126].

\subsection{BILF1; a Conserved G Protein-Coupled Receptor in $\gamma 1$-Herpesviruses}

\subsubsection{General}

BILF1 is a glycosylated viral GPCR (vGPCR) of around $50 \mathrm{kDa}$ (33 kDa unglycosylated) encoded by EBV. This receptor has been shown to mainly associate to the cell membrane of EBV-infected cells [2]. This receptor ticks several boxes of GPCRs, such as signaling through $G$ proteins, containing seven transmembrane helices and displaying conserved cysteine residues in ECLs and the N-terminus. However, BILF1 has an alternative DRY motif at the intracellular end of TM-3. Instead of the well-conserved triad of aspartic acid, arginine and tyrosine (DRY), known among many as rhodopsin-like GPCRs (Class A 
GPCRs), BILF1 presents an alternative, while similar, DRY-motif (EKT), which maintains the respective charges of the residues [2].

In 2015, 21 orthologs of BILF1 were identified in primate and ungulate $\gamma 1$-herpesviruses. Among these orthologs, several conserved regions, most intriguingly in the extracellular loops (ECLs) and predominantly in ECL-2, were found [127]. Likewise, these orthologs contain conserved cysteines in ECL-2 and on top of TM-3 (GPCR bridge), and in the Nterminus and the top of TM-7 (chemokine receptor/CKR bridge), both of which are known to form a disulfide bridge in rhodopsin-like 7TM receptors [118,128]. Similarly, NF- $\mathrm{kB}$ activation and G $\alpha$ i signaling are conserved among EBV-BILF1 and studied primate BILF1 orthologs. Moreover, the mentioned study on BILF1 orthologs [127] and a recent study from 2020 [129] also generated data strongly indicating constitutive internalization and recycling of BILF1.

As displayed in numerous studies, DRY /EKT motif in TM-3 is essential for G protein signaling [122,130] and can be disrupted by a K122A substitution [15,122]. In contrast to other vGPCRs such as US28 and ORF74, which primarily signal through G $\alpha$ q [3,131-133] (but also G $\alpha$ i $[131,134,135])$, BILF1 solely, ligand independently and constitutively signals via the $\mathrm{G} \alpha \mathrm{i}$ class of $\mathrm{G}$ proteins, while activating NF- $\mathrm{kB}$ and modulating cAMP-response element (CRE) gene regulation pathways $[2,3,16,136]$.

\subsubsection{Structure}

Unlike other vGPCRs binding CC or CXC chemokines [131] and potentially acting as chemokine scavengers, no endogenous ligand for BILF1 has been found [2,3]. This has led to the general classification of BILF1 as an "orphan" receptor. However, recent studies on elucidating its structure suggest a molecularly evolved ligand-independency of BILF1 [137]. In contrast to common chemokine receptors, this vGPCR displays an unusual conformation. In fact, BILF1 structurally resembles lipid GPCRs rather than chemokine receptors. Here, ECL-2 binds into its own extracellular vestibule, forming a lid. Together with an inward-facing ECL-3, this blocks access of potential ligands to the extracellular binding pocket. In the light of acting as a "self-antagonist", the previously mentioned conserved regions of ECL-2 among various BILF1 orthologs [127] could prove essential for this lid-forming ability of BILF1. Consequently, the expression "orphan receptor" does not adequately represent the hypothesis that BILF1 "willingly" does not require any ligand for activation. Rather than relying on soluble ligands for activation, it appears that this receptor has acquired several mutations in typical class A GPCR motifs, leading to robust and constitutive activation and signaling [137]. In addition to the previously outlined topologic particularities of BILF1, this study revealed a unique Gai-binding interface with higher specificity in comparison to endogenous Gai-binding GPCRs. This could facilitate BILF1's putative G-protein scavenging properties.

\subsubsection{Expression Patterns}

BILF1 has been detected in various $\mathrm{EBV}^{+}$cell lines and tissue samples in lytic and latent programs but is mainly considered a lytic protein $[3,17,122,138-141]$. Table 3 displays this matter in more detail by listing malignancies with (not ubiquitously) detected BILF1 expression. This receptor has been described as an early lytic protein, though, curiously, BILF1 was shown to progressively interfere with MHC-I antigen presentation throughout the lytic cycle $[16,17,138,139]$. 
Table 3. Summary of cell lines and tissue samples with detected BILF1 expression.

\begin{tabular}{|c|c|c|c|}
\hline Name/EBV-Associated Malignancy & Latency & Type & References \\
\hline AIDS-related lymphoma (ARL) & I-III & Tissue sample & [140] \\
\hline Angioimmunoblastic T-cell lymphoma (AITL) & II & Tissue sample & {$[22,140]$} \\
\hline Anaplastic large cell lymphoma (ALCL) & II ? & Tissue sample & {$[140]$} \\
\hline Burkitt lymphoma (BL) & I & Tissue sample & {$[22,138]$} \\
\hline $\begin{array}{c}\text { Classical Hodgkin lymphoma, nodular } \\
\text { sclerosis (cHL-NS) }\end{array}$ & II & Tissue sample & [140] \\
\hline Cutaneous T-cell lymphoma (CTCL) & II ? & Tissue sample & [140] \\
\hline Diffuse large B-cell lymphoma (DLBCL) & I-III & Tissue sample & {$[22,140]$} \\
\hline Gastric carcinoma (GC) & I & Tissue sample & {$[22,141]$} \\
\hline Mature T- and NK-cell lymphoma (MTNKL) & II & Tissue sample & [22] \\
\hline Nasopharyngeal carcinoma (NPC) & II & Tissue sample & {$[22]$} \\
\hline $\begin{array}{l}\text { Nodular lymphocyte predominant Hodgkin } \\
\text { lymphoma (NLPHL) }\end{array}$ & II & Tissue sample & [140] \\
\hline $\begin{array}{l}\text { Peripheral T-cell lymphoma, not otherwise } \\
\text { specified (PTCL-NOS) }\end{array}$ & II & Tissue sample & [140] \\
\hline B95-8 (LCL) & III & Cell line & {$[3,17,140]$} \\
\hline HH514.c16 (BL) & I & Cell line & [3] \\
\hline Jijoye (BL) & I & Cell line & {$[140]$} \\
\hline JY (LCL) & III & Cell line & {$[3]$} \\
\hline KREB2 (LCL) & III & Cell line & [140] \\
\hline MEC04 (MTNKL) & II & Cell line & [140] \\
\hline MLEB2 (LCL) & III & Cell line & [140] \\
\hline Namalwa (BL) & $\mathrm{I}$ & Cell line & {$[3,140]$} \\
\hline P3HR1 (BL) & I & Cell line & [140] \\
\hline Raji (BL) & I & Cell line & {$[139,140]$} \\
\hline SNK6 (MTNKL) & II & Cell line & [140] \\
\hline Various BL cell lines & I & Cell line & [138] \\
\hline X50-7 (LCL) & III & Cell line & {$[3]$} \\
\hline
\end{tabular}

? not fully elucidated. Abbreviations: ALR, AIDS-related lymphoma; AITL, angioimmunoblastic T-cell lymphoma ALCL, anaplastic large cell lymphoma; BL, Burkitt lymphoma; cHL-NS, classical Hodgkin lymphoma, nodular sclerosis; CTCL, cutaneous T-cell lymphoma; DLBCL, diffuse large B-cell lymphoma; GC, gastric carcinoma; LCL, lymphoblastoid cell line; MTNKL, mature T- and NK-cell lymphoma; NPC, nasopharyngeal carcinoma; NLPHL, nodular lymphocyte predominant Hodgkin lymphoma; PTCL-NOS, peripheral T-cell lymphoma, not otherwise specified.

\subsubsection{Cellular Effects}

BILF1 has been shown to modulate several systems of the host cell in order to persist in the host. As an initial evasion mechanism, this receptor has been associated to the inhibition of phosphorylation of the RNA-dependent Protein Kinase (PKR) [3]. This interferes with a cellular antiviral defense mechanism, which normally intends to stop protein synthesis and initiate apoptosis of infected cells, hence minimizing virus spread.

As indicated above, BILF1 is able to interfere with host defense mechanisms against EBV through various distinct mechanisms. One major mechanism besides inactivating PKR is the downregulation of MHC-I receptors on the surface of host cells, effectively avoiding a strong $\mathrm{CD} 8^{+}$T-lymphocyte (cytotoxic T-cell, CTL) response and, hence, evading quick and efficient eradication of EBV by the host immune system $[15,16,136]$. In several investigations, it has been indicated that BILF1 must somehow, through its intracellular C-terminal tail, physically interact with the HLA-I molecule (more specifically its heavy chain), as $\triangle C$-terminus mutated versions of BILF1 were not able to downregulate MHC-I surface presentation $[16,136]$. This downregulation is proposed to occur through BILF1directed degradation of MHC-I molecules in lysosomes, as lysosomal inhibitors were able to prevent degradation [15]. Even though a first study did not deem signaling ability (intact EKT motif) important for MHC-I downregulation [15], subsequent studies have suggested signaling-independent importance of an intact EKT motif for MHC-I internalization $[16,142]$. Additionally, besides triggering internalization and degradation of HLA-I molecules, BILF1 also diverts freshly synthesized MHC class I peptide complexes during 
exocytosis, causing a decrease in membrane-bound MHC-I and proteasome-derived peptide presentation [16]. The mechanism for this effect seems to be independent of the EKT motif and C-terminus.

Furthermore, recent mutational studies on the roles of conserved amino acids (AA) in the extracellular loops (ECLs) revealed that these residues are also directly or indirectly essential for surface downregulation of MHC class I molecules [142]. Interestingly, BILF1 significantly reduces the presentation of HLA-A, HLA-B and HLA-E classes, while having negligible effect on HLA-C subtypes of MHC-I molecules [136]. Through this, EBV could be able to evade strong CTL responses (mainly mediated through HLA-A and -B) while preventing activation of HLA-C-binding NK-cells [136]. Figure 4 summarizes the aforementioned BILF1-associated MHC-I downregulation, while also illustrating constitutive internalization and G $\alpha$ i signaling through BILF1.

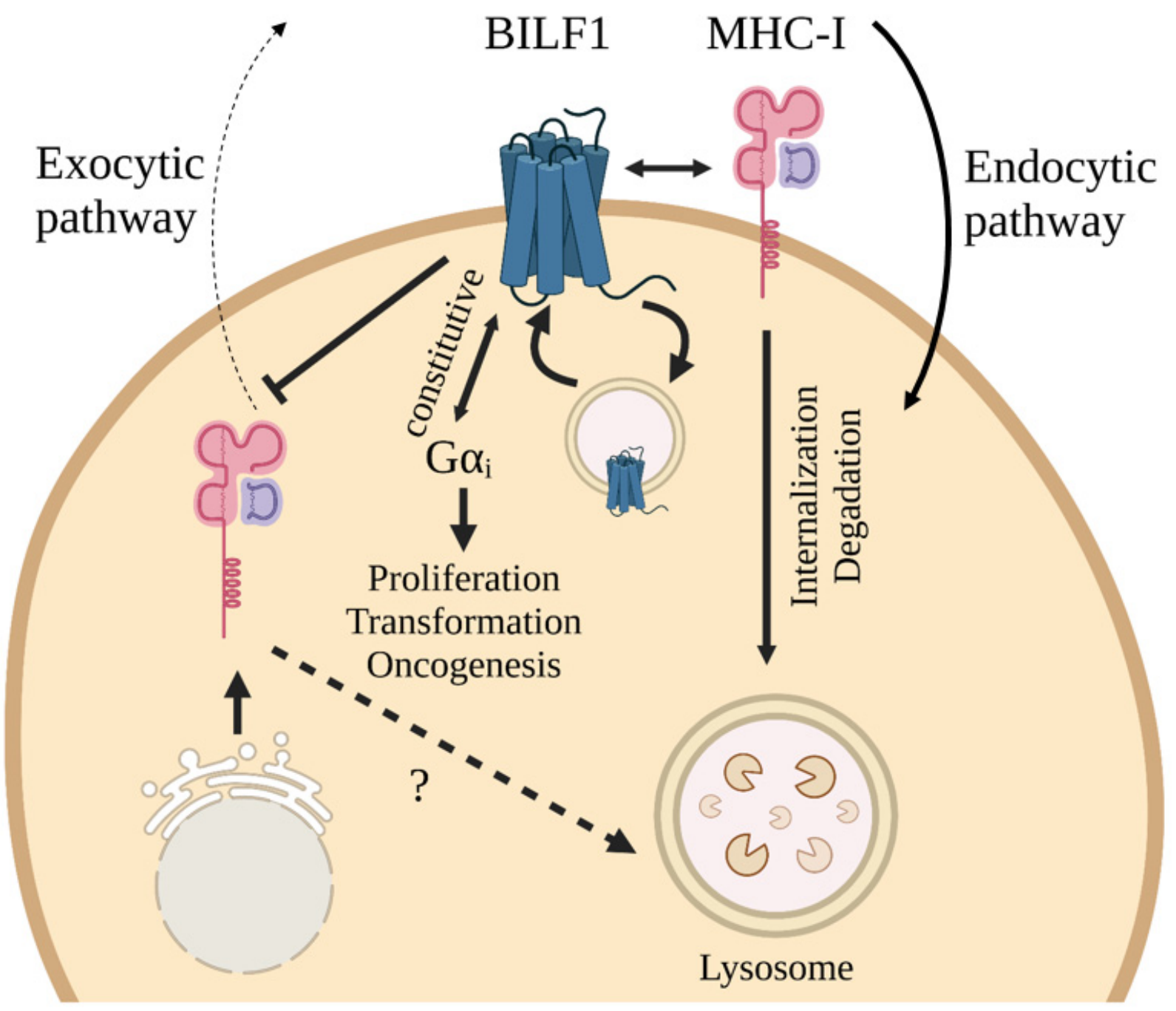

Figure 4. Constitutive signaling and internalization of EBV-BILF1, and its effects on oncogenesis and MHC class I downregulation. In the endocytic pathway, BILF1 physically interacts with MHC-I at the plasma membrane and promotes MHC-I internalization. In the exocytic pathway, BILF1 drives the inhibition of surface expression of newly synthesized MHC-I molecules. Constitutive signaling though G $\alpha$ i results in cell proliferation, transformation and oncogenesis. Created with BioRender.com. 
Besides its proposed physical interaction with MHC-I, BILF1 has been described to form heteromers with endogenous chemokine receptors [143,144]. Especially, the interaction between BILF1 and CXCR4 has been surveyed, wherein co-expression of these receptors resulted in impaired CXCL12 binding to CXCR4 [144]. This effect seems to be (BILF1) signaling-dependent and is thought to be achieved through the physical stabilization of an un-inducible CXCR4 conformation within the BILF1:CXCR4 heteromer and/or through BILF1-associated constitutive G protein scavenging, possibly leading to the absence of allosteric modulation of the agonist-binding site. Furthermore, BILF1 assembled into heteromers with the histamine receptor $\mathrm{H}_{4} \mathrm{R}$, which did not hinder histamine binding, but EKT motif-dependently eliminated $\mathrm{H}_{4} \mathrm{R}$ signaling to CREB. Taken together, it seems more plausible that BILF1 actively inhibits endogenous receptors through its persistent scavenging of G $\alpha$ i proteins. A BILF1-induced reduction of plasma B cell migration toward organs with high CXCL12 expression has been discussed [144]. This could be advantageous for EBV replication and dissemination and thus could be part of the virus's sophisticated survival mechanisms [144].

\subsubsection{Oncogenesis}

In addition to decreasing surface presentation of MHC-I, a study by Lyngaa et al. revealed convincing tumor-promoting effects of BILF1, making BILF1 an oncogene [122]. In this study, G $\alpha$ i signaling-dependent transformation of NIH-3T3 cells was observed in vitro and in vivo in a mouse xenograft model. In vitro foci formation assays with BILF1 ${ }^{+}$ NIH-3T3 cells expressing the wild type (EKT-motif) or one of two mutations (DRY and EAT) showed strong foci induction, which correlated with the amount of constitutive signaling. While the wild type with strong signaling profile induced foci formation with the highest frequency, the DRY mutant (intermediate activity) formed foci with a minimal but significant frequency, and the EAT mutant (no activity) did not produce a significant number of foci compared to the negative control. Another in vitro experiment in this study demonstrated that only the BILF1 wild type, but not the EAT mutant, was able to overcome NIH-3T3 cell contact inhibition, stimulate cell transformation and signalingdependently increase vascular endothelial growth factor (VEGF) secretion. Correlating to EBV-associated malignancies, increases in VEGF secretion have been linked to both non-Hodgkin's lymphomas [145] and nasopharyngeal carcinomas [146]. Intriguingly, the bilateral injection of wild type BILF1 ${ }^{+}$cells in nude mice provoked tumor development in $100 \%$ of the mice and $87.5 \%$ of injection sites, whereas only $60 \%$ of the mice and $40 \%$ of injections sites resulted in tumor development in mice injected with the EAT mutant of BILF1. The fact that the signaling-deficient EAT mutant was able to induce tumor formation led to the conclusion that the oncogenic properties of BILF1 are not exclusively associated with constitutive signaling through $\mathrm{G} \alpha \mathrm{i}$. Figure 2B displays an exemplary image of a BILF1-induced tumor in this nude mouse model.

Linked to NF-KB activation, BILF1 has recently been found to upregulate the intercellular adhesion molecule-1 (ICAM-1) [139]. As ICAM-1 upregulation has been connected to various types of cancer and might promote cancer metastasis [147], a causative link between BILF1 expression and ICAM-1 upregulation may be valuable to elucidate mechanisms of EBV oncogenicity. Being an NF- $\mathrm{kB}$ dependent gene, mutational studies on the NF- $\mathrm{kB}$-binding sites of the ICAM-1 promoter were undertaken, which revealed a significant disruption of the BILF1-linked upregulation of this promoter. Moreover, the cellular level of the endogenous NF- $\kappa B$ inhibitor protein, I $\kappa \mathrm{B} \alpha$, decreased BILF1-dependently, likely resulting in the translocation of NF- $\mathrm{KB}$ from the cytoplasm into the nucleus [139].

Summarizing, the picture that BILF1 is painting in terms of association to diseases is becoming quite clear-its role in immune evasion and oncogenesis has been elucidated extensively. The current data suggests that targeting BILF1 with a novel therapeutic might be a way to treat several EBV-associated malignancies. This and the targeting of other GPCRs will be the topic of the next chapter. 


\subsection{Druggability of GPCRs}

As GPCRs constitute a large family of receptors imperative for cell signaling, malfunctions can lead to a manifold of different diseases. Consequently, many drugs have been developed to modulate certain GPCRs. Currently, around 34\% (481) of all FDA-approved drugs target 107 unique GPCRs [1]. In fact, 69 new drugs have been FDA-approved within the last 5 years, and, as of 2017, 320 drugs, of which 114 are novel drugs acting on 64 novel GPCRs, were under investigation in clinical trials. The diseases and GPCRs in focus are extremely diverse: Metabolic disorders such as hyperparathyroidism (calcium-sensing receptor) [148] and diabetes type 2 (GLP-1 receptor and GPR119 among others) [149]; psychiatric disorders such as schizophrenia (dopamine receptor $\mathrm{D}_{2}$ ) [150]; central nervous system-related diseases such as multiple sclerosis (sphingosine 1-phosphate phosphate receptor 1) [151]; several types of cancer [1,152,153]; and viruses like HIV-1 (CCR5) [154].

Based on the link between previously presented vGPCRs (including BILF1) and tumorigenesis, the general druggability of GPCRs in the context of cancer is briefly outlined [152,153]. Research has revealed several mechanisms through which GPCRs can promote oncogenesis:

- Excess of circulating agonists driving GPCR signaling, which promotes tumor progression (e.g., neuropeptides in small cell lung cancer) [155];

- Mutations in GPCRs or G $\alpha$ subunit leading to aberrant signaling (e.g., G stimulatory protein ( $g s p)$, thyroid-stimulating hormone receptor (TSHR) [156]);

- Overexpression of certain GPCRs (e.g., among many others, CXCR4, CCR7 or CXCR1) resulting in increased cancer metastasis, proliferation, cell survival or angiogenesis [157]

The latter mechanism is exploited by the monoclonal antibody ulocuplumab, as it blocks CXCR4 and induces apoptosis in a chronic lymphocytic leukemia (CLL) model [157]. To date, it is not yet FDA-approved. GPCR-targeting anti-cancer drugs with FDA approval are mainly small molecules (sonidegib, vismodegib, cabergoline, raloxifene, brigatinib), but peptides (lanreaotide, degarelix, leuprolide) and mAbs (mogamulizumab, erenumab) are also currently in use [152,153]. The fact that there are already therapeutics targeting GPCRs in cancer-with many more to come-illustrates the general feasibility of GPCR targeting in this context, which could likely also be translated to vGPCR-positive malignancies.

In fact, this is not a new idea: In 1999, Rosenkilde et al. constructed a $\mathrm{Zn}^{2+}$ binding double-mutant Kaposi sarcoma herpes virus (KSHV) GPCR ORF74 in order to study the effects of a potential ORF74-specific small molecule drug [158]. Intriguingly, incubation with $\mathrm{Zn}^{2+}$ blocked the constitutive signaling of ORF74 with an $\mathrm{EC}_{50}$ of $1 \mu \mathrm{M}$. This observed inverse agonism indicated the possibility of targeting ORF74 extracellularly with a small molecule ligand, which could potentially interfere with ORF74-driven oncogenesis.

In a different approach, KSHV has also successfully been targeted through immunotoxins binding to lytic glycoproteins and thus killing lytically infected cells in a selective manner $[159,160]$. Though this can be of benefit in a productive infection, the latent reservoir of this herpesvirus remains untouched, allowing the virus to persist in the host.

Additionally, within the last 20 years, a lot of effort has been put into developing human cytomegalovirus (HCMV) GPCR US28-specific therapeutics, most of which are small molecules [161-164]. These small molecules displayed inverse agonistic and neutral antagonistic properties, while reaching $\mathrm{EC}_{50}$ values in the lower micromolar range. In a recent effort to find additional US28-binding small molecules, over 12 million molecules from the ZINC database were screened in silico, resulting in a library of 98 potential candidates [165]. After conducting inositolphosphate (IP) accumulation and $\mathrm{Ca}^{2+}$ mobilization assays, two promising compounds, ZINC36408696 and ZINC38535746, with respective agonistic and inverse agonistic properties, decent potency $(0.95 \mu \mathrm{M}$ and $1.76 \mu \mathrm{M}$, respectively) and limited cross-reactivity on other receptors but without CX3CL1 displacing capabilities were identified. In a follow-up study, a new library of commercially available small molecules containing 78 potential US28 modulators was assembled based on the structures of the previously identified compounds [166]. IP accumulation and binding 
assays revealed several molecules with improvements regarding efficacy and potency compared with the "original" inverse agonist identified in the previous study. Moreover, competitive binding of many of these molecules with CCL2 and CCL4, but not CX3CL1, was observed. These first-in-class studies lay the basis for future development in US28 targeting and modulating small molecules.

Most recently, a research group from the Vrije Universiteit Amsterdam published three highly interesting papers on US28 involvement and targeting in glioblastoma [167-169]. Starting chronologically, the first study describes the successful development of a US28specific single-domain antibody ( $\mathrm{sdAb}$ ), also called nanobody $(\mathrm{Nb})$ or variable heavy fragment (VHH), with sub micromolar affinity [167]. The bivalent version of this nanobody specifically inhibited ligand-dependent and constitutive US28 signaling and hence interfered with US28-driven glioblastoma growth in vitro and in vivo in an orthotopic xenograft mouse model. In a subsequent study [168], the group selected another US28-specific, highaffinity ( $\mathrm{k}_{\mathrm{D}}$ of $2 \mathrm{nM}$ ) nanobody and conjugated this with a photosensitizer (IRDye700DX) in order to be used in targeted photodynamic therapy. In vitro binding assays showed improved displacement of CX3CL1 and killing assays on US28-expressing glioblastoma cells generated compelling data in 2D cultures and 3D spheroids. Finally, in the latest study (preprint, not yet peer-reviewed), the previous monovalent nanobody was developed into a bivalent version [169]. This increased the binding affinity to US28 once again (by 10-fold, to $0.2 \mathrm{nM}$ ) and retained the ability to inhibit constitutive US28 signaling by $50 \%$, which makes this new construct a partial inverse agonist to US28. Through this inhibition, CMV was partially reactivated in latently infected primary $\mathrm{CD} 14^{+}$monocytes and expressed IE genes with only marginal expression of immunoevasins. In the clinic, this could make CMV more detectable to the host immune system, which in turn could promote eradication of the virus.

Similarly, targeting and exploiting a vGPCR with constitutive internalization, a chemokine-ExoA based immunotoxin against HCMV-US28 has been developed [170-172]. In these studies, the preferred chemokine to bind US28, CX3CL1, was linked to an ExoA moiety. Additionally, in order to obtain selectivity between US28 and the endogenous CX3CL1 receptor (CX3CR1), a mutated F49A-CX3CL1 was engineered. Due to the constitutive internalizing nature of US28, it has proven to be an ideal target for this kind of treatment, allowing the FTP to efficiently piggyback into the cell. This resulted in a highly potent and selective immunotoxin targeting lytically as well as latently infecting cells, as US28 is expressed in both cycles of CMV. Examples such as the latter clearly indicate the potential of targeting constitutively internalizing viral GPCRs in next-generation antivirals.

The results of all presented studies emphasize the high druggability of the vGPCR US28 and serve as starting points for future development of anti-HCMV medication and as role models for therapeutics targeting of other vGPCRs.

Addressing the need of EBV-specific therapeutics, research on EBV-targeting immunotoxins for nasopharyngeal carcinoma (NPC) has been published [173,174]. These immunotoxins have been shown to selectively kill LMP-1 or LMP-2 expressing NPC cells, respectively, in both in vitro assays and in vivo mouse models. The drawback here is also the incomplete eradication of the virus. As lytic cells do not generally express the latent membrane proteins, these cells would largely remain untouched during the immunotoxin treatment.

BILF1 is the focus of this review and has been suggested as a potential drug target, although research data on BILF1 druggability are scarce. Investigating novel ways to exploit BILF1 in future therapeutics and being aware of the absence of any known endogenous ligands, a research group in 2015 engineered EBV-BILF1 to contain a metal ion binding site through mutations in two transmembrane regions [142], based on the previously mentioned proof-of-concept for ORF74 [158]. This mutated version of BILF1 and the wild type receptor were subsequently incubated with phenanthroline (ZnPhe) or bipyridine (ZnBip) in a $\mathrm{Zn}^{2+}$ complex and examined for G $\alpha$ i signaling activity in an IP3 accumulation assay in HEK-293 cells co-transfected with $\mathrm{G} \alpha_{\mathrm{qi} 4 \mathrm{my}}$. The chimeric $\mathrm{G}$ protein $\mathrm{G} \alpha_{\mathrm{qi}}$ my couples to $\mathrm{G} \alpha \mathrm{i}$ binding 
GPCRs as a G $\alpha$ i but signals similar to G $\alpha q$, leading to accumulation of IP3 through CRE activation by phospholipase C. While the wild type BILF1 was not affected, ZnBip and $\mathrm{ZnPhe}$ decreased the constitutive activity of the double mutant by around $30 \%$ with a respective $\mathrm{EC}_{50}$ of 2 and $1 \mu \mathrm{M}$. Beside the observed inverse agonism, both metal chelators increased the surface expression of the double mutant by $30-40 \%$, while, solely in the case of ZnBip, also promoting surface expression of wild type BILF1 by $15 \%$ at $10 \mu \mathrm{M}$. Finally, the MHC-I downregulation by wild type BILF1 was inhibited by $10 \%$, and by $15 \%$ for the double mutant. In conclusion, this proof-of-concept demonstrated the potential druggability of BILF1 through small molecules, effectively acting as inverse agonists and, hence, possibly inhibiting BILF1's role in EBV pathology.

\section{EBV Drug Pipeline}

Tables 4-7 contain a snapshot of the EBV drug pipeline, extracted from GlobalData.com in 2020. As seen in Tables 5 and 6, most drugs in development are based on cellular immunotherapy or small molecules. Additionally, three respective mAb therapeutics (Table 4) and vaccines (Table 7) are presently being developed.

The antibody pipeline mostly focusses on checkpoint inhibitors against the programmed cell death protein 1 (PD-1) and cytotoxic T-lymphocyte-associated Protein 4 (CTLA-4), but an antibody targeting the thymidine kinase 1 (TK1) is also being researched. In terms of cellular immunotherapy, several different autologous and allogeneic EBVspecific cytotoxic T-lymphocyte treatments targeting several EBV-derived epitopes (EBNA1, LMP1, LMP2, BARF-1) are under development. The majority of the investigated vaccines encode for EBV glycoproteins, which ideally should prevent EBV infections. Interestingly, one vaccine candidate is targeted toward the latent proteins EBNA1 and LMP2, as it is aimed to be used in patients with persistent, recurrent or metastatic nasopharyngeal carcinoma. While the aforementioned therapeutics almost exclusively focus on EBV-derived proteins as targets, the small molecule pipeline aims to interfere with various endogenous proteins, though EBV-specific molecules modulating EBNA1 and BZLF1 are also being investigated.

The fact that several different groups are looking into novel therapeutics to tackle EBV-associated malignancies shows the great need of efficacious and selective strategies and the fact that investing in the EBV-therapeutics market might be a financially attractive opportunity, despite still being in its infancy.

Table 4. Antibody pipeline for EBV-linked malignancies.

\begin{tabular}{ccccc}
\hline Indication & Drug Name & Action & Development Stage & Identifier \\
\hline $\begin{array}{c}\text { (Non-) Hodgkin } \\
\text { lymphoma }\end{array}$ & $\begin{array}{c}\text { ipilimumab }+ \\
\text { nivolumab }\end{array}$ & $\alpha$-CTLA-4 $+\alpha$-PD-1 & Phase II & NCT01592370 \\
\hline B cell lymphoma & nivolumab & $\alpha$-PD-1 & Phase I & NCT03097939 \\
\hline B cell lymphoma & Viroprev & $\alpha$-TK1 & IND application & $\begin{array}{c}\text { //savoypharmaceuticals. } \\
\text { com/viroprev.php, accessed } \\
\text { on 12 August 2021 }\end{array}$ \\
\hline
\end{tabular}


Table 5. Cellular immunotherapy pipeline for EBV-linked malignancies.

\begin{tabular}{|c|c|c|c|c|}
\hline Indication & Drug Name & Action & Development Stage & Identifier \\
\hline $\begin{array}{l}\text { Nasopharyngeal } \\
\text { carcinoma (NPC) }\end{array}$ & & Autologous EBV T Cells & Phase II & NCT00834093 \\
\hline $\begin{array}{l}\text { NPC, first-line in } \\
\text { combination with } \\
\text { gemcitabine }+ \\
\text { carboplatin }\end{array}$ & TT10 EBVSTs & $\begin{array}{c}\text { Autologous EBV-CTL } \\
\text { (EBNA1, BARF-1, LMP) }\end{array}$ & Phase III & NCT02578641 \\
\hline $\begin{array}{c}\mathrm{NPC} \\
\text { relapse/refractory }\end{array}$ & YT-E001 & $\begin{array}{c}\text { Autologous EBV-CTL } \\
\text { (EBNA1, LMP1, LMP2) }\end{array}$ & Phase I/II & NCT03648697 \\
\hline NPC & LT-C50 & EBV-CTL & Preclinical & $\begin{array}{c}\text { https://liontcr.com/ } \\
\text { pipeline/, accessed on } \\
12 \text { August } 2021\end{array}$ \\
\hline Gastric Carcinoma & LT-C60 & EBV-CTL & Preclinical & $\begin{array}{c}\text { https://liontcr.com/ } \\
\text { pipeline/, accessed on } \\
12 \text { August } 2021\end{array}$ \\
\hline $\begin{array}{c}\mathrm{NPC} \\
\text { recurrent/metastatic } \\
\text { (platinum-pretreated) }\end{array}$ & $\begin{array}{l}\text { Tabelecleucel + } \\
\text { pembrolizumab }\end{array}$ & Allogeneic EBV-CTL & Phase $\mathrm{Ib} / \mathrm{II}$ & NCT03769467 \\
\hline $\begin{array}{c}\text { CD30+ } \\
\text { EBV-lymphomas }\end{array}$ & TT11x & $\begin{array}{c}\text { Autologous EBV-CTL } \\
(\text { EBNA1, BARF-1, LMP) + } \\
\text { CD30 CAR }\end{array}$ & Phase I & NCT04288726 \\
\hline EBV+ PTLD & $\begin{array}{l}\text { Viralym-M } \\
\text { (ALVR105) }\end{array}$ & $\begin{array}{l}\text { Multi-virus specific } \\
\text { allogenic T-Cells }\end{array}$ & Phase II & NCT04693637 \\
\hline $\begin{array}{c}\text { Post HSCT } \\
\text { opportunistic infections }\end{array}$ & & $\begin{array}{c}\text { Autologous or allogenic } \\
\text { EBV CTL }\end{array}$ & Phase II & NCT03159364 \\
\hline $\begin{array}{l}\text { EBV+ PTLD after SOT } \\
\text { or alloHCT (after } \\
\text { failure of } \\
\text { rituximab } / r+\text { chemo) }\end{array}$ & tabelecleucel & Allogeneic EBV-CTL & Phase III & NCT03394365 \\
\hline $\begin{array}{c}\text { EBV+ PTLD after } \\
\text { alloHCT (after failure } \\
\text { of rituximab) }\end{array}$ & tabelecleucel & Allogeneic EBV-CTL & Phase III & NCT03392142 \\
\hline $\begin{array}{l}\text { Progressive multiple } \\
\text { sclerosis }\end{array}$ & ATA-188 & Allogeneic EBV-CTL & Phase I & NCT03283826 \\
\hline $\begin{array}{l}\text { Advanced stage EBV+ } \\
\text { malignancies (stage IV } \\
\text { gastric carcinoma, NPC, } \\
\text { lymphoma after SOC) }\end{array}$ & & $\begin{array}{c}\text { Autologous PD-1 } \\
\text { knockout } \\
\text { EBV-CTL + Fludarabine + } \\
\text { Cyclophosphamide + } \\
\text { IL-2 }\end{array}$ & Phase II & NCT03044743 \\
\hline $\begin{array}{c}\text { Systemic Lupus } \\
\text { Erythematosus (SLE) }\end{array}$ & LUPUS CTL EBV & Autologous EBV-CTL & Phase I/II & NCT02677688 \\
\hline ENKTCL, (PTLD, NPC) & VT-EBV-N & $\begin{array}{l}\text { Autologous EBV CTL } \\
\text { (LMP1, LMP2a) }\end{array}$ & Phase II & NCT03671850 \\
\hline ENKTCL, 2nd line & EBViNT & $\begin{array}{l}\text { Autologous EBV CTL } \\
\text { (LMP2a) }\end{array}$ & Phase I/II & NCT03789617 \\
\hline $\begin{array}{l}\text { Reactivation/infection } \\
\text { prevention post cord } \\
\text { blood transplant }\end{array}$ & & Autologous EBV CTL & Phase I/II & $\begin{array}{l}\text { NCT03594981 } \\
\text { NCT01923766 }\end{array}$ \\
\hline
\end{tabular}


Table 6. Small molecule pipeline for EBV-linked malignancies.

\begin{tabular}{|c|c|c|c|c|}
\hline Indication & Drug Name & Action & Development Stage & Identifier \\
\hline $\begin{array}{l}\text { NPC, 3rd line, locally } \\
\text { recurrent or metastatic }\end{array}$ & apatinib mesylate & $\begin{array}{l}\text { Vascular endothelial } \\
\text { growth factor receptor } \\
2 \text { (VEGFR-2) inhibitor }\end{array}$ & Phase II & NCT03130270 \\
\hline EBV+ Lymphoma & $\begin{array}{l}\text { Nanatinostat } \\
(\mathrm{VRx}-3996)\end{array}$ & $\begin{array}{l}\text { Histone deacetylase } \\
\text { (HDAC) inhibitor }\end{array}$ & Phase I/II & NCT03397706 \\
\hline $\begin{array}{c}\text { Viral cancers/EBV } \\
\text { diseases }\end{array}$ & & Inhibition of replication & Lead selection & $\begin{array}{l}\text { http://www.virostatics. } \\
\text { com/research-and- } \\
\text { development/, accessed } \\
\text { on } 12 \text { August } 2021\end{array}$ \\
\hline EBV diseases & & BZLF1 activator & Discovery & $\begin{array}{l}\text { http:/ / www.vironika. } \\
\text { com/pipeline, accessed } \\
\text { on } 12 \text { August } 2021\end{array}$ \\
\hline EBV diseases & & EBNA1 inhibitor & Pre-IND & $\begin{array}{l}\text { http:/ / www.vironika. } \\
\text { com/pipeline, accessed } \\
\text { on } 12 \text { August } 2021\end{array}$ \\
\hline
\end{tabular}

Table 7. EBV-specific vaccine pipeline.

\begin{tabular}{|c|c|c|c|c|}
\hline Indication & Drug Name & Action & Development Stage & Identifier \\
\hline $\begin{array}{l}\text { Persistent, recurrent or } \\
\text { metastatic NPC }\end{array}$ & MVA vaccine & $\begin{array}{l}\text { Recombinant modified } \\
\text { vaccinia Ankara (MVA) } \\
\text { EBNA1/LMP2 vaccine }\end{array}$ & Phase II & NCT01094405 \\
\hline EBV infection & mRNA-1189 & $\begin{array}{c}\text { mRNA-based vaccine } \\
\text { (gp350, gH/gL/gp42, } \\
\text { gH/gL, gB) }\end{array}$ & Preclinical & $\begin{array}{l}\text { https://www.modernatx. } \\
\text { com/pipeline, accessed on } \\
12 \text { August } 2021\end{array}$ \\
\hline EBV infection & Vaccine & gp350 blocking & Phase I recruitment & NCT04645147 \\
\hline EBV infection & Vaccine & g42, gH/gL blocking & Preclinical & $\begin{array}{c}\text { 10.1016/j.immuni.2019.03.010, } \\
\text { Patent No. EP3054971, } \\
\text { accessed on } 12 \text { August 2021 }\end{array}$ \\
\hline
\end{tabular}

\section{Conclusions}

EBV ubiquitously and persistently infects the grand majority of adults worldwide, and a large number of patients suffer from EBV-associated malignancies every year. Currently, these patients do not have access to EBV-specific therapeutics. Rather, they are treated with common regimens of surgery, chemotherapy, radiotherapy and, potentially, immunotherapy. It is therefore of high interest to discover and develop alternative and EBV-specific treatment strategies. As outlined in this review, there is significant ongoing development of many new and promising drug and vaccine strategies for EBV-associated diseases. Nonetheless, more options are needed. Given the general druggability of GPCRs and the previously successful targeting of another vGPCR (US28), an EBV-encoded GPCR could prove a viable drug target. BILF1 has the potential to be considered a target as such, due to its role in EBV pathology, its internalizing nature and its expression in several EBV-malignancies. Hence, BILF1 should be considered a future drug target for the treatment of EBV-mediated diseases. In order to confirm its potential, more research on BILF1 expression patterns (especially in EBV-malignancies) and druggability must be conducted.

Author Contributions: Conceptualization, J.M.K., T.N.K. and M.M.R.; resources, T.N.K. and M.M.R.; writing—original draft preparation, J.M.K.; writing—review and editing, J.M.K. and M.M.R.; visualization, J.M.K.; supervision, T.N.K. and M.M.R.; funding acquisition, T.N.K. and M.M.R. All authors have read and agreed to the published version of the manuscript. 
Funding: This research was funded by NovoNordisk Foundation, grant number PreSeed Grant, 2018.

Data Availability Statement: Data available in a publicly accessible repository.

Acknowledgments: We thank Mads Gravers Jeppesen, Synklino, Denmark for fruitful discussions during the writing of this review.

Conflicts of Interest: T.N.K. and M.M.R. are co-founders of the biotech company Synklino, Denmark.

\section{References}

1. Hauser, A.S.; Attwood, M.M.; Rask-Andersen, M.; Schiöth, H.B.; Gloriam, D.E. Trends in GPCR drug discovery: New agents, targets and indications. Nat. Rev. Drug Discov. 2017, 16, 829-842. [CrossRef]

2. Paulsen, S.J.; Rosenkilde, M.M.; Eugen-Olsen, J.; Kledal, T.N. Epstein-Barr Virus-Encoded BILF1 Is a Constitutively Active G Protein-Coupled Receptor. J. Virol. 2005, 79, 536-546. [CrossRef]

3. Beisser, P.S.; Verzijl, D.; Gruijthuijsen, Y.K.; Beuken, E.; Smit, M.J.; Leurs, R.; Bruggeman, C.A.; Vink, C. The Epstein-Barr Virus BILF1 Gene Encodes a G Protein-Coupled Receptor That Inhibits Phosphorylation of RNA-Dependent Protein Kinase. J. Virol. 2005, 79, 441-449. [CrossRef]

4. Cohen, J.I. Epstein-Barr Virus Infection. N. Engl. J. Med. 2000, 343, 481-492. [CrossRef] [PubMed]

5. Ambinder, R.F.; Cesarman, E. Clinical and Pathological Aspects of EBV and KSHV Infection; Arvin, A., Campadelli-Fiume, G., Mocarski, E., Moore, P.S., Roizman, B., Whitley, R., Yamanishi, K., Eds.; Cambridge University Press: Cambridge, UK, 2007; ISBN 9780521827140.

6. Wang, F.; Rivailler, P.; Rao, P.; Cho, Y. Simian homologues of Epstein-Barr virus. Philos. Trans. R. Soc. Lond. Ser. B Biol. Sci. 2001, 356, 489-497. [CrossRef] [PubMed]

7. Epstein, M.; Achong, B.; Barr, Y. Virus Particles in Cultured Lymphoblasts from Burkitt's Lymphoma. Lancet 1964, $283,702-703$. [CrossRef]

8. Arfelt, K.N.; Fares, S.; Rosenkilde, M.M. EBV, the human host, and the 7TM receptors: Defense or offense? In Progress in Molecular Biology and Translational Science; Elsevier: Amsterdam, The Netherlands, 2015; Volume 129, pp. 395-427.

9. Babcock, G.J.; Decker, L.L.; Volk, M.; Thorley-Lawson, D.A. EBV Persistence in Memory B Cells In Vivo. Immunity 1998, 9, 395-404. [CrossRef]

10. Chesnokova, L.S.; Hutt-Fletcher, L.M. Fusion of Epstein-Barr Virus with Epithelial Cells Can Be Triggered by $\alpha v \beta 5$ in Addition to $\alpha v \beta 6$ and $\alpha v \beta 8$, and Integrin Binding Triggers a Conformational Change in Glycoproteins gHgL. J. Virol. 2011, 85, 13214-13223. [CrossRef]

11. Hutt-Fletcher, L.M. Epstein-Barr Virus Entry. J. Virol. 2007, 81, 7825-7832. [CrossRef]

12. Tanner, J.; Weis, J.; Fearon, D.; Whang, Y.; Kieff, E. Epstein-barr virus gp350/220 binding to the B lymphocyte C3d receptor mediates adsorption, capping, and endocytosis. Cell 1987, 50, 203-213. [CrossRef]

13. Kenney, S.C. Reactivation and lytic replication of EBV. In Human Herpesviruses; Arvin, A., Campadelli-Fiume, G., Mocarski, E., Moore, P.S., Roizman, B., Whitley, R., Yamanishi, K., Eds.; Cambridge University Press: Cambridge, UK, 2007 ; pp. 403-433.

14. Murata, T. Encyclopedia of EBV-encoded lytic genes: An update. In Advances in Experimental Medicine and Biology; Springer: New York, NY, USA, 2018; Volume 1045, pp. 395-412.

15. Zuo, J.; Currin, A.; Griffin, B.D.; Shannon-Lowe, C.; Thomas, W.A.; Ressing, M.E.; Wiertz, E.J.H.J.; Rowe, M. The Epstein-Barr Virus G-Protein-Coupled Receptor Contributes to Immune Evasion by Targeting MHC Class I Molecules for Degradation. PLoS Pathog. 2009, 5, e1000255. [CrossRef] [PubMed]

16. Zuo, J.; Quinn, L.L.; Tamblyn, J.; Thomas, W.A.; Feederle, R.; Delecluse, H.-J.; Hislop, A.D.; Rowe, M. The Epstein-Barr Virus-Encoded BILF1 Protein Modulates Immune Recognition of Endogenously Processed Antigen by Targeting Major Histocompatibility Complex Class I Molecules Trafficking on both the Exocytic and Endocytic Pathways. J. Virol. 2011, 85, 1604-1614. [CrossRef]

17. Quinn, L.L.; Zuo, J.; Abbott, R.J.M.; Shannon-Lowe, C.; Tierney, R.J.; Hislop, A.D.; Rowe, M. Cooperation between Epstein-Barr Virus Immune Evasion Proteins Spreads Protection from CD8+ T Cell Recognition across All Three Phases of the Lytic Cycle. PLoS Pathog. 2014, 10, e1004322. [CrossRef] [PubMed]

18. Quinn, L.L.; Williams, L.R.; White, C.; Forrest, C.; Zuo, J.; Rowe, M. The Missing Link in Epstein-Barr Virus Immune Evasion: The BDLF3 Gene Induces Ubiquitination and Downregulation of Major Histocompatibility Complex Class I (MHC-I) and MHC-II. J. Virol. 2016, 90, 356-367. [CrossRef] [PubMed]

19. Kanda, T. EBV-encoded latent genes. In Advances in Experimental Medicine and Biology; Springer: New York, NY, USA, 2018; Volume 1045, pp. 377-394.

20. Ambrosio, M.R.; Leoncini, L. Epidemiology of Epstein-Barr Virus and Mechanisms of Carcinogenesis. In Tropical Hemato-Oncology; Springer International Publishing: Cham, Switzerland, 2015; pp. 127-141, ISBN 9783319182575.

21. Young, L.S.; Rickinson, A.B. Epstein-Barr virus: 40 years on. Nat. Rev. Cancer 2004, 4, 757-768. [CrossRef] 
22. Chakravorty, S.; Yan, B.; Wang, C.; Wang, L.; Quaid, J.T.; Lin, C.F.; Briggs, S.D.; Majumder, J.; Canaria, D.A.; Chauss, D.; et al. Integrated Pan-Cancer Map of EBV-Associated Neoplasms Reveals Functional Host-Virus Interactions. Cancer Res. 2019, 79, 6010-6023. [CrossRef]

23. Frappier, L. Epstein-Barr virus: Current questions and challenges. Tumour Virus Res. 2021, 12, 200218. [CrossRef]

24. Hjalgrim, H.; Friborg, J.; Melbye, M. The Epidemiology of EBV and Its Association with Malignant Disease; Cambridge University Press: Cambridge, UK, 2007; ISBN 9780521827140.

25. Siaghani, P.J.; Wong, J.T.; Chan, J.; Weisenburger, D.D.; Song, J.Y. Epidemiology and Pathology of T- and NK-Cell Lymphomas. In Cancer Treatment and Research; Springer International Publishing: New York, NY, USA, 2019; Volume 176, pp. 1-29.

26. Houen, G.; Trier, N.H.; Frederiksen, J.L. Epstein-Barr Virus and Multiple Sclerosis. Front. Immunol. 2020, 11. [CrossRef]

27. Hassani, A.; Corboy, J.R.; Al-Salam, S.; Khan, G. Epstein-Barr virus is present in the brain of most cases of multiple sclerosis and may engage more than just B cells. PLoS ONE 2018, 13, e0192109. [CrossRef] [PubMed]

28. Guan, Y.; Jakimovski, D.; Ramanathan, M.; Weinstock-Guttman, B.; Zivadinov, R. The role of Epstein-Barr virus in multiple sclerosis: From molecular pathophysiology to in vivo imaging. Neural Regen. Res. 2019, 14, 373. [CrossRef]

29. Aygun, D.; Kuskucu, M.A.; Sahin, S.; Adrovic, A.; Barut, K.; Yıldız, M.; Sharifova, S.; Midilli, K.; Cokugras, H.; Camcıglu, Y.; et al. Epstein-Barr virus, cytomegalovirus and BK polyomavirus burden in juvenile systemic lupus erythematosus: Correlation with clinical and laboratory indices of disease activity. Lupus 2020, 29, 1263-1269. [CrossRef]

30. Li, Z.-X.; Zeng, S.; Wu, H.-X.; Zhou, Y. The risk of systemic lupus erythematosus associated with Epstein-Barr virus infection: A systematic review and meta-analysis. Clin. Exp. Med. 2019, 19, 23-36. [CrossRef] [PubMed]

31. Draborg, A.H.; Duus, K.; Houen, G. Epstein-Barr Virus and Systemic Lupus Erythematosus. Clin. Dev. Immunol. 2012, 2012, 1-10. [CrossRef] [PubMed]

32. Farahmand, M.; Monavari, S.H.; Shoja, Z.; Ghaffari, H.; Tavakoli, M.; Tavakoli, A. Epstein-Barr virus and risk of breast cancer: A systematic review and meta-analysis. Future Oncol. 2019, 15, 2873-2885. [CrossRef]

33. Hu, H.; Luo, M.-L.; Desmedt, C.; Nabavi, S.; Yadegarynia, S.; Hong, A.; Konstantinopoulos, P.A.; Gabrielson, E.; Hines-Boykin, R.; Pihan, G.; et al. Epstein-Barr Virus Infection of Mammary Epithelial Cells Promotes Malignant Transformation. EBioMedicine 2016, 9, 148-160. [CrossRef]

34. Sinclair, A.J.; Moalwi, M.H.; Amoaten, T. Is EBV Associated with Breast Cancer in Specific Geographic Locations? Cancers 2021, 13, 819. [CrossRef]

35. Jin, Q.; Su, J.; Yan, D.; Wu, S. Epstein-Barr Virus Infection and Increased Sporadic Breast Carcinoma Risk: A Meta-Analysis. Med. Princ. Pract. 2020, 29, 195-200. [CrossRef]

36. Rosenkilde, M.; Kledal, T. Targeting Herpesvirus Reliance of the Chemokine System. Curr. Drug Targets 2006, 7, 103-118. [CrossRef]

37. Rezk, S.A.; Zhao, X.; Weiss, L.M. Epstein-Barr virus (EBV)-associated lymphoid proliferations, a 2018 update. Hum. Pathol. 2018, 79, 18-41. [CrossRef] [PubMed]

38. Cuccaro, A.; Bartolomei, F.; Cupelli, E.; Hohaus, S. Prognostic factors in Hodgkin Lymphoma. Mediterr. J. Hematol. Infect. Dis. 2014, 6, e2014053. [CrossRef]

39. Kimura, H. EBV in T-/NK-Cell Tumorigenesis. In Advances in Experimental Medicine and Biology; Springer: New York, NY, USA, 2018; Volume 1045, pp. 459-475.

40. Kimura, H.; Fujiwara, S. Overview of EBV-Associated T/NK-Cell Lymphoproliferative Diseases. Front. Pediatr. 2019, 6, 417. [CrossRef]

41. Cohen, J.I. Vaccine Development for Epstein-Barr Virus. In Advances in Experimental Medicine and Biology; Springer: New York, NY, USA, 2018; Volume 1045, pp. 477-493.

42. WHO. Hodgkin Lymphoma in 2018; GLOBOCAN 2018; WHO: Geneva, Switzerland, 2018.

43. Casulo, C.; Friedberg, J. Treating Burkitt Lymphoma in Adults. Curr. Hematol. Malig. Rep. 2015, 10, 266-271. [CrossRef]

44. Burkitt, D. A “Tumour Safari” in East and Central Africa. Br. J. Cancer 1962, 16, 379-386. [CrossRef]

45. Yamaguchi, M.; Miyazaki, K. Current treatment approaches for NK/T-cell lymphoma. J. Clin. Exp. Hematop. 2017, 57, 98-108. [CrossRef] [PubMed]

46. Tang, Y.-T.; Wang, D.; Luo, H.; Xiao, M.; Zhou, H.-S.; Liu, D.; Ling, S.-P.; Wang, N.; Hu, X.-L.; Luo, Y.; et al. Aggressive NK-cell leukemia: Clinical subtypes, molecular features, and treatment outcomes. Blood Cancer J. 2017, 7, 660. [CrossRef]

47. Lunning, M.A.; Vose, J.M. Angioimmunoblastic T-cell lymphoma: The many-faced lymphoma. Blood 2017, 129, 1095-1102. [CrossRef]

48. Querfeld, C.; Zain, J.; Rosen, S.T. T-Cell and NK-Cell Lymphomas; Cancer Treatment and Research; Springer International Publishing: Cham, Switzerland, 2019; Volume 176, ISBN 978-3-319-99715-5.

49. Gru, A.A.; Haverkos, B.H.; Freud, A.G.; Hastings, J.; Nowacki, N.B.; Barrionuevo, C.; Vigil, C.E.; Rochford, R.; Natkunam, Y.; Baiocchi, R.A.; et al. The Epstein-Barr Virus (EBV) in T Cell and NK Cell Lymphomas: Time for a Reassessment. Curr. Hematol. Malig. Rep. 2015, 10, 456-467. [CrossRef]

50. Swerdlow, S.H.; Campo, E.; Harris, N.L.; Jaffe, E.S.; Pileri, S.A.; Stein, H.; Thiele, J. WHO Classification of Tumours of Haematopoietic and Lymphoid Tissues, 4th ed.; IARC: Lyon, France, 2017; Volume 2, ISBN 978-92-832-4494-3.

51. WHO. Non-Hodgkin Lymphoma in 2018; GLOBOCAN 2018; WHO: Geneva, Switzerland, 2018. 
52. Dunleavy, K.; Roschewski, M.; Wilson, W.H. Lymphomatoid Granulomatosis and Other Epstein-Barr Virus Associated Lymphoproliferative Processes. Curr. Hematol. Malig. Rep. 2012, 7, 208-215. [CrossRef]

53. Gutiérrez-Domingo, Á.; Gutiérrez-Domingo, I.; Gallardo-Rodríguez, K.M. Lymphomatoid Granulomatosis: A Rare Tumor with Poor Prognosis. Arch. Bronconeumol. 2018, 54, 108-109. [CrossRef] [PubMed]

54. Roschewski, M.; Wilson, W.H. Lymphomatoid Granulomatosis. Cancer J. 2012, 18, 469-474. [CrossRef] [PubMed]

55. Song, J.Y.; Pittaluga, S.; Dunleavy, K.; Grant, N.; White, T.; Jiang, L.; Davies-Hill, T.; Raffeld, M.; Wilson, W.H.; Jaffe, E.S. Lymphomatoid Granulomatosis-A Single Institute Experience. Am. J. Surg. Pathol. 2015, 39, 141-156. [CrossRef]

56. Chen, Y.-P.; Chan, A.T.C.; Le, Q.-T.; Blanchard, P.; Sun, Y.; Ma, J. Nasopharyngeal carcinoma. Lancet 2019, 394, 64-80. [CrossRef]

57. Houldcroft, C.J.; Kellam, P. Host genetics of Epstein-Barr virus infection, latency and disease. Rev. Med. Virol. 2015, 25, 71-84. [CrossRef] [PubMed]

58. Khan, G.; Hashim, M.J. Global burden of deaths from Epstein-Barr virus attributable malignancies 1990-2010. Infect. Agent. Cancer 2014, 9, 38. [CrossRef] [PubMed]

59. Farrell, P.J. Epstein-Barr Virus and Cancer. Annu. Rev. Pathol. Mech. Dis. 2019, 14, 29-53. [CrossRef] [PubMed]

60. WHO. Nasopharyngeal Carcinoma in 2018; GLOBOCAN 2018; WHO: Geneva, Switzerland, 2018.

61. Nishikawa, J.; Iizasa, H.; Yoshiyama, H.; Shimokuri, K.; Kobayashi, Y.; Sasaki, S.; Nakamura, M.; Yanai, H.; Sakai, K.; Suehiro, Y.; et al. Clinical Importance of Epstein-Barr Virus-Associated Gastric Cancer. Cancers 2018, 10, 167. [CrossRef] [PubMed]

62. Naseem, M.; Barzi, A.; Brezden-Masley, C.; Puccini, A.; Berger, M.D.; Tokunaga, R.; Battaglin, F.; Soni, S.; McSkane, M.; Zhang, W.; et al. Outlooks on Epstein-Barr virus associated gastric cancer. Cancer Treat. Rev. 2018, 66, 15-22. [CrossRef]

63. Kang, B.W.; Baek, D.W.; Kang, H.; Baek, J.H.; Kim, J.G. Novel Therapeutic Approaches for Epstein-Barr Virus Associated Gastric Cancer. Anticancer Res. 2019, 39, 4003-4010. [CrossRef]

64. Sitarz, R.; Skierucha, M.; Mielko, J.; Offerhaus, J.; Maciejewski, R.; Polkowski, W. Gastric cancer: Epidemiology, prevention, classification, and treatment. Cancer Manag. Res. 2018, 10, 239-248. [CrossRef]

65. Fukayama, M. Epstein-Barr virus and gastric carcinoma. Pathol. Int. 2010, 60, 337-350. [CrossRef]

66. WHO. Stomach Cancer in 2018; GLOBOCAN 2018; WHO: Geneva, Switzerland, 2018.

67. Cheng, N.; Hui, D.; Liu, Y.; Zhang, N.; Jiang, Y.; Han, J.; Li, H.; Ding, Y.; Du, H.; Chen, J.; et al. Is gastric lymphoepithelioma-like carcinoma a special subtype of EBV-associated gastric carcinoma? New insight based on clinicopathological features and EBV genome polymorphisms. Gastric Cancer 2015, 18, 246-255. [CrossRef]

68. Iezzoni, J.C.; Gaffey, M.J.; Weiss, L.M. The Role of Epstein-Barr Virus in Lymphoepithelioma-like Carcinomas. Am. J. Clin. Pathol. 1995, 103, 308-315. [CrossRef]

69. Díaz del Arco, C.; Esteban Collazo, F.; Fernández Aceñero, M.J. Lymphoepithelioma-like carcinoma of the large intestine: A case report and literature review. Rev. Esp. Patol. 2018, 51, 18-22. [CrossRef]

70. Labgaa, I.; Stueck, A.; Ward, S.C. Lymphoepithelioma-Like Carcinoma in Liver. Am. J. Pathol. 2017, 187, 1438-1444. [CrossRef] [PubMed]

71. Koufopoulos, N.; Syrios, J.; Papanikolaou, A.; Misitzis, I.; Kapatou, K.A.; Dimas, D.; Khaldi, L. Lymphoepithelioma-like breast carcinoma. Pol. J. Pathol. 2018, 69, 98-104. [CrossRef] [PubMed]

72. Yang, W.-J.; Qiao, Y.-W.; Zhao, X.-Q.; Liu, J. Clinicopathological features of Epstein-Barr virus-associated gastric carcinoma: A systematic review and meta-analysis. J. Balk. Union Oncol. 2019, 24, 1092-1099.

73. Bittar, Z.; Fend, F.; Quintanilla-Martinez, L. Lymphoepithelioma-like carcinoma of the stomach: A case report and review of the literature. Diagn. Pathol. 2013, 8, 184. [CrossRef]

74. Bai, Y.; Gao, Q.; Ren, G.; Wang, B.; Xiang, H. Epstein-Barr virus-associated lymphoepithelioma-like gastric carcinoma located on gastric high body: Two case reports. Indian J. Pathol. Microbiol. 2014, 57, 463. [CrossRef] [PubMed]

75. Bedri, S.; Sultan, A.A.; Alkhalaf, M.; Al Moustafa, A.-E.; Vranic, S. Epstein-Barr virus (EBV) status in colorectal cancer: A mini review. Hum. Vaccin. Immunother. 2019, 15, 603-610. [CrossRef]

76. WHO. Breast Cancer in 2018; GLOBOCAN 2018; WHO: Geneva, Switzerland, 2018.

77. Münz, C. Epstein Barr Virus Volume 1; Current Topics in Microbiology and Immunology; Springer International Publishing: Cham, Switzerland, 2015; Volume 390, ISBN 978-3-319-22821-1.

78. Li, S.; Young, K.H.; Medeiros, L.J. Diffuse large B-cell lymphoma. Pathology 2018, 50, 74-87. [CrossRef]

79. Castillo, J.J.; Beltran, B.E.; Miranda, R.N.; Young, K.H.; Chavez, J.C.; Sotomayor, E.M. EBV-positive diffuse large B-cell lymphoma, not otherwise specified: 2018 update on diagnosis, risk-stratification and management. Am. J. Hematol. 2018, 93, 953-962. [CrossRef]

80. Lu, T.-X.; Liang, J.-H.; Miao, Y.; Fan, L.; Wang, L.; Qu, X.-Y.; Cao, L.; Gong, Q.-X.; Wang, Z.; Zhang, Z.-H.; et al. Epstein-Barr virus positive diffuse large B-cell lymphoma predict poor outcome, regardless of the age. Sci. Rep. 2015, 5, 12168. [CrossRef]

81. Liu, Y.; Barta, S.K. Diffuse large B-cell lymphoma: 2019 update on diagnosis, risk stratification, and treatment. Am. J. Hematol. 2019, 94, 604-616. [CrossRef]

82. Green, M.; Michaels, M.G. Epstein-Barr Virus Infection and Posttransplant Lymphoproliferative Disorder. Am. J. Transplant. 2013, 13, 41-54. [CrossRef] [PubMed]

83. Montoto, S.; Wilson, J.; Shaw, K.; Heath, M.; Wilson, A.; McNamara, C.; Orkin, C.; Nelson, M.; Johnson, M.; Bower, M.; et al. Excellent immunological recovery following CODOX-M/IVAC, an effective intensive chemotherapy for HIV-associated Burkitt's lymphoma. AIDS 2010, 24, 851-856. [CrossRef] 
84. Jacobson, C.A.; Abramson, J.S. HIV-Associated Hodgkin's Lymphoma: Prognosis and Therapy in the Era of cART. Adv. Hematol. 2012, 2012, 1-8. [CrossRef]

85. Lopez, A.; Abrisqueta, P. Plasmablastic lymphoma: Current perspectives. Blood Lymphat. Cancer Targets Ther. 2018, 8, 63-70. [CrossRef]

86. Tchernonog, E.; Faurie, P.; Coppo, P.; Monjanel, H.; Bonnet, A.; Algarte Génin, M.; Mercier, M.; Dupuis, J.; Bijou, F.; Herbaux, C.; et al. Clinical characteristics and prognostic factors of plasmablastic lymphoma patients: Analysis of 135 patients from the LYSA group. Ann. Oncol. 2017, 28, 843-848. [CrossRef]

87. Gravelle, P.; Péricart, S.; Tosolini, M.; Fabiani, B.; Coppo, P.; Amara, N.; Traverse-Gléhen, A.; Van Acker, N.; Brousset, P.; Fournie, J.-J.; et al. EBV infection determines the immune hallmarks of plasmablastic lymphoma. Oncoimmunology 2018, 7, e1486950. [CrossRef] [PubMed]

88. Grogg, K.L.; Miller, R.F.; Dogan, A. HIV infection and lymphoma. J. Clin. Pathol. 2006, 60, 1365-1372. [CrossRef] [PubMed]

89. UNAIDS. Global HIV \& AIDS Statistics-2020 Fact Sheet. Available online: https://www.unaids.org/en/resources/fact-sheet (accessed on 27 May 2021).

90. Bibas, M.; Antinori, A. EBV and HIV-Related Lymphoma. Mediterr. J. Hematol. Infect. Dis. 2009, 1, e2009032. [CrossRef] [PubMed]

91. GODT. WHO International Report on Organ Donation and Transplantation Activities 2019; Executive Summary 2019; WHO: Geneva, Switzerland, 2021; pp. 1-12.

92. Dharnidharka, V.R.; Webster, A.C.; Martinez, O.M.; Preiksaitis, J.K.; Leblond, V.; Choquet, S. Post-transplant lymphoproliferative disorders. Nat. Rev. Dis. Prim. 2016, 2, 15088. [CrossRef]

93. Lee, B.; Bower, M.; Newsom-Davis, T.; Nelson, M. HIV-related lymphoma. HIV Ther. 2010, 4, 649-659. [CrossRef]

94. Rosen, S.T. HIV/AIDS-Associated Viral Oncogenesis; Meyers, C., Ed.; Cancer Treatment and Research; Springer International Publishing: Cham, Switzerland, 2019; Volume 177, ISBN 978-3-030-03501-3.

95. Wu, D.; Chen, C.; Zhang, M.; Li, Z.; Wang, S.; Shi, J.; Zhang, Y.; Yao, D.; Hu, S. The clinical features and prognosis of 100 AIDS-related lymphoma cases. Sci. Rep. 2019, 9, 5381. [CrossRef]

96. Gopal, S.; Patel, M.R.; Yanik, E.L.; Cole, S.R.; Achenbach, C.J.; Napravnik, S.; Burkholder, G.A.; Reid, E.G.; Rodriguez, B.; Deeks, S.G.; et al. Temporal Trends in Presentation and Survival for HIV-Associated Lymphoma in the Antiretroviral Therapy Era. J. Natl. Cancer Inst. 2013, 105, 1221-1229. [CrossRef] [PubMed]

97. Meister, A.; Hentrich, M.; Wyen, C.; Hübel, K. Malignant lymphoma in the HIV-positive patient. Eur. J. Haematol. 2018, 101, 119-126. [CrossRef] [PubMed]

98. Nowalk, A.; Green, M. Epstein-Barr Virus. Microbiol. Spectr. 2016, 4. [CrossRef] [PubMed]

99. Gross, T.G.; Orjuela, M.A.; Perkins, S.L.; Park, J.R.; Lynch, J.C.; Cairo, M.S.; Smith, L.M.; Hayashi, R.J. Low-Dose Chemotherapy and Rituximab for Posttransplant Lymphoproliferative Disease (PTLD): A Children's Oncology Group Report. Am. J. Transplant. 2012, 12, 3069-3075. [CrossRef] [PubMed]

100. Dekate, J.; Chetty, R. Epstein-Barr Virus-Associated Smooth Muscle Tumor. Arch. Pathol. Lab. Med. 2016, 140, 718-722. [CrossRef]

101. Hussein, K.; Rath, B.; Ludewig, B.; Kreipe, H.; Jonigk, D. Clinico-pathological characteristics of different types of immunodeficiency-associated smooth muscle tumours. Eur. J. Cancer 2014, 50, 2417-2424. [CrossRef]

102. Prockop, S.E.; Doubrovina, E.; Boulad, F.; Kernan, N.A.; Kobos, R.; Scaradavou, A.; Abramson, S.J.; Laquaglia, M.; Price, A.; O’Reilly, R.J. Adoptive Treatment Of EBV-Associated Leiomyosarcoma in Immunodeficient Patients With EBV Specific Cytotoxic T Cells. Blood 2013, 122, 3267. [CrossRef]

103. Jonigk, D.; Laenger, F.; Maegel, L.; Izykowski, N.; Rische, J.; Tiede, C.; Klein, C.; Maecker-Kolhoff, B.; Kreipe, H.; Hussein, K. Molecular and Clinicopathological Analysis of Epstein-Barr Virus-Associated Posttransplant Smooth Muscle Tumors. Am. J. Transplant. 2012, 12, 1908-1917. [CrossRef]

104. Magg, T.; Schober, T.; Walz, C.; Ley-Zaporozhan, J.; Facchetti, F.; Klein, C.; Hauck, F. Epstein-Barr Virus+ Smooth Muscle Tumors as Manifestation of Primary Immunodeficiency Disorders. Front. Immunol. 2018, 9, 368. [CrossRef]

105. Pender, M.P.; Csurhes, P.A.; Smith, C.; Douglas, N.L.; Neller, M.A.; Matthews, K.K.; Beagley, L.; Rehan, S.; Crooks, P.; Hopkins, T.J.; et al. Epstein-Barr virus-specific T cell therapy for progressive multiple sclerosis. JCI Insight 2018, 3, e124714. [CrossRef]

106. Dunleavy, K.; Pittaluga, S.; Shovlin, M.; Steinberg, S.M.; Cole, D.; Grant, C.; Widemann, B.; Staudt, L.M.; Jaffe, E.S.; Little, R.F.; et al. Low-Intensity Therapy in Adults with Burkitt's Lymphoma. N. Engl. J. Med. 2013, 369, 1915-1925. [CrossRef] [PubMed]

107. Thomas, D.A.; Faderl, S.; O’Brien, S.; Bueso-Ramos, C.; Cortes, J.; Garcia-Manero, G.; Giles, F.J.; Verstovsek, S.; Wierda, W.G.; Pierce, S.A.; et al. Chemoimmunotherapy with hyper-CVAD plus rituximab for the treatment of adult Burkitt and Burkitt-type lymphoma or acute lymphoblastic leukemia. Cancer 2006, 106, 1569-1580. [CrossRef] [PubMed]

108. Sweetenham, J.W.; Pearce, R.; Taghipour, G.; Blaise, D.; Gisselbrecht, C.; Goldstone, A.H. Adult Burkitt's and Burkitt-like non-Hodgkin's lymphoma-Outcome for patients treated with high-dose therapy and autologous stem-cell transplantation in first remission or at relapse: Results from the European Group for Blood and Marrow Transplantation. J. Clin. Oncol. 1996, 14, 2465-2472. [CrossRef]

109. Oriol, A.; Ribera, J.; Bergua, J.; Giménez Mesa, E.; Grande, C.; Esteve, J.; Brunet, S.; Moreno, M.; Escoda, L.; Hernandez-Rivas, J.; et al. High-dose chemotherapy and immunotherapy in adult Burkitt lymphoma. Cancer 2008, 113, 117-125. [CrossRef]

110. Haahr, S.; Höllsberg, P. Multiple sclerosis is linked to Epstein-Barr virus infection. Rev. Med. Virol. 2006, 16, 297-310. [CrossRef] [PubMed]

111. WHO. Atlas: Multiple Sclerosis in the World in 2008; WHO: Geneva, Switzerland, 2008. 
112. Fernández-Menéndez, S.; Fernández-Morán, M.; Fernández-Vega, I.; Pérez-Álvarez, A.; Villafani-Echazú, J. Epstein-Barr virus and multiple sclerosis. From evidence to therapeutic strategies. J. Neurol. Sci. 2016, 361, 213-219. [CrossRef]

113. Laurence, M.; Benito-León, J. Epstein-Barr virus and multiple sclerosis: Updating Pender's hypothesis. Mult. Scler. Relat. Disord. 2017, 16, 8-14. [CrossRef]

114. Lucas, R.M.; Hughes, A.M.; Lay, M.-L.J.; Ponsonby, A.-L.; Dwyer, D.E.; Taylor, B.V.; Pender, M.P. Epstein-Barr virus and multiple sclerosis. J. Neurol. Neurosurg. Psychiatry 2011, 82, 1142-1148. [CrossRef] [PubMed]

115. Nicholas, R.; Rashid, W. Multiple sclerosis. BMJ Clin. Evid. 2012, 10, 1202.

116. Alexander, S.P.H.; Davenport, A.P.; Kelly, E.; Marrion, N.; Peters, J.A.; Benson, H.E.; Faccenda, E.; Pawson, A.J.; Sharman, J.L.; Southan, C.; et al. The Concise Guide to Pharmacology 2015/16: G protein-coupled receptors. Br. J. Pharmacol. 2015, 172, 5744-5869. [CrossRef]

117. Weis, W.I.; Kobilka, B.K. The Molecular Basis of G Protein-Coupled Receptor Activation. Annu. Rev. Biochem. 2018, 87, 897-919. [CrossRef]

118. Mirzadegan, T.; Benko, G.; Filipek, S.; Palczewski, K. Sequence Analyses of G-Protein-Coupled Receptors: Similarities to Rhodopsin. Biochemistry 2003, 42, 2759. [CrossRef] [PubMed]

119. Rovati, G.E.; Capra, V.; Neubig, R.R. The Highly Conserved DRY Motif of Class A G Protein-Coupled Receptors: Beyond the Ground State. Mol. Pharmacol. 2007, 71, 959-964. [CrossRef]

120. Trzaskowski, B.; Latek, D.; Yuan, S.; Ghoshdastider, U.; Debinski, A.; Filipek, S. Action of Molecular Switches in GPCRsTheoretical and Experimental Studies. Curr. Med. Chem. 2012, 19, 1090-1109. [CrossRef]

121. Wacker, D.; Stevens, R.C.; Roth, B.L. How Ligands Illuminate GPCR Molecular Pharmacology. Cell 2017, 170, 414-427. [CrossRef]

122. Lyngaa, R.; Nørregaard, K.; Kristensen, M.; Kubale, V.; Rosenkilde, M.M.; Kledal, T.N. Cell transformation mediated by the Epstein-Barr virus G protein-coupled receptor BILF1 is dependent on constitutive signaling. Oncogene 2010, 29, 4388-4398. [CrossRef]

123. Downes, G.B.; Gautam, N. The G Protein Subunit Gene Families. Genomics 1999, 62, 544-552. [CrossRef] [PubMed]

124. Dhanasekaran, N.; Dermott, J.M. Signaling by the G12 class of G proteins. Cell. Signal. 1996, 8, 235-245. [CrossRef]

125. Suzuki, N.; Hajicek, N.; Kozasa, T. Regulation and physiological functions of G12/13-mediated signaling pathways. NeuroSignals 2009, 17, 55-70. [CrossRef]

126. Komolov, K.E.; Du, Y.; Duc, N.M.; Betz, R.M.; Rodrigues, J.P.G.L.M.; Leib, R.D.; Patra, D.; Skiniotis, G.; Adams, C.M.; Dror, R.O.; et al. Structural and Functional Analysis of a ß2-Adrenergic Receptor Complex with GRK5. Cell 2017, 169, 407-421.e16. [CrossRef]

127. Spiess, K.; Fares, S.; Sparre-Ulrich, A.H.; Hilgenberg, E.; Jarvis, M.A.; Ehlers, B.; Rosenkilde, M.M. Identification and Functional Comparison of Seven-Transmembrane G-Protein-Coupled BILF1 Receptors in Recently Discovered Nonhuman Primate Lymphocryptoviruses. J. Virol. 2015, 89, 2253-2267. [CrossRef]

128. Rummel, P.C.; Thiele, S.; Hansen, L.S.; Petersen, T.P.; Sparre-Ulrich, A.H.; Ulven, T.; Rosenkilde, M.M. Extracellular Disulfide Bridges Serve Different Purposes in Two Homologous Chemokine Receptors, CCR1 and CCR5. Mol. Pharmacol. 2013, 84, 335-345. [CrossRef]

129. Mavri, M.; Spiess, K.; Rosenkilde, M.M.; Rutland, C.S.; Vrecl, M.; Kubale, V. Methods for Studying Endocytotic Pathways of Herpesvirus Encoded G Protein-Coupled Receptors. Molecules 2020, 25, 5710. [CrossRef]

130. Rosenkilde, M.M.; Smit, M.J.; Waldhoer, M. Structure, function and physiological consequences of virally encoded chemokine seven transmembrane receptors. Br. J. Pharmacol. 2008, 153, 154-166. [CrossRef] [PubMed]

131. Rosenkilde, M.M.; Waldhoer, M.; Lüttichau, H.R.; Schwartz, T.W. Virally encoded 7TM receptors. Oncogene 2001, 20 , 1582-1593. [CrossRef] [PubMed]

132. Casarosa, P.; Bakker, R.A.; Verzijl, D.; Navis, M.; Timmerman, H.; Leurs, R.; Smiti, M.J. Constitutive signaling of the human cytomegalovirus-encoded chemokine receptor US28. J. Biol. Chem. 2001, 276, 1133-1137. [CrossRef]

133. Geras-Raaka, E.; Arvanitakis, L.; Bais, C.; Cesarman, E.; Mesri, E.A.; Gershengorn, M.C. Inhibition of Constitutive Signaling of Kaposi's Sarcoma-Associated Herpesvirus G Protein-Coupled Receptor by Protein Kinases in Mammalian Cells in Culture. J. Exp. Med. 1998, 187, 801-806. [CrossRef] [PubMed]

134. Smit, M.J.; Verzijl, D.; Casarosa, P.; Navis, M.; Timmerman, H.; Leurs, R. Kaposi's Sarcoma-Associated Herpesvirus-Encoded G Protein-Coupled Receptor ORF74 Constitutively Activates p44/p42 MAPK and Akt via Gi and Phospholipase C-Dependent Signaling Pathways. J. Virol. 2002, 76, 1744-1752. [CrossRef]

135. Couty, J.P.; Geras-Raaka, E.; Weksler, B.B.; Gershengorn, M.C. Kaposi's Sarcoma-associated Herpesvirus G Protein-coupled Receptor Signals through Multiple Pathways in Endothelial Cells. J. Biol. Chem. 2001, 276, 33805-33811. [CrossRef]

136. Griffin, B.D.; Gram, A.M.; Mulder, A.; Van Leeuwen, D.; Claas, F.H.J.; Wang, F.; Ressing, M.E.; Wiertz, E. EBV BILF1 Evolved to Downregulate Cell Surface Display of a Wide Range of HLA Class I Molecules through Their Cytoplasmic Tail. J. Immunol. 2013, 190, 1672-1684. [CrossRef]

137. Tsutsumi, N.; Qu, Q.; Mavri, M.; Baggesen, M.S.; Maeda, S.; Waghray, D.; Berg, C.; Kobilka, B.K.; Rosenkilde, M.M.; Skiniotis, G.; et al. Structural basis for the constitutive activity and immunomodulatory properties of the Epstein-Barr virus-encoded $\mathrm{G}$ protein-coupled receptor BILF1. Immunity 2021, 54, 1405-1416. [CrossRef] 
138. Tierney, R.J.; Shannon-Lowe, C.D.; Fitzsimmons, L.; Bell, A.I.; Rowe, M. Unexpected patterns of Epstein-Barr virus transcription revealed by a High throughput PCR array for absolute quantification of viral mRNA. Virology 2015, 474, 117-130. [CrossRef] [PubMed]

139. Guo, Q.; Gao, J.; Cheng, L.; Yang, X.; Li, F.; Jiang, G. The Epstein-Barr virus-encoded G protein-coupled receptor BILF1 upregulates ICAM-1 through a mechanism involving the NF- $\mathrm{kB}$ pathway. Biosci. Biotechnol. Biochem. 2020, 84, 1810-1819. [CrossRef]

140. Bayda, N.; Tilloy, V.; Chaunavel, A.; Bahri, R.; Halabi, M.A.; Feuillard, J.; Jaccard, A.; Ranger-Rogez, S. Comprehensive EpsteinBarr Virus Transcriptome by RNA-Sequencing in Angioimmunoblastic T Cell Lymphoma (AITL) and Other Lymphomas. Cancers 2021, 13, 610. [CrossRef] [PubMed]

141. Borozan, I.; Zapatka, M.; Frappier, L.; Ferretti, V. Analysis of Epstein-Barr Virus Genomes and Expression Profiles in Gastric Adenocarcinoma. J. Virol. 2017, 92. [CrossRef]

142. Fares, S.; Spiess, K.; Olesen, E.T.B.; Zuo, J.; Jackson, S.; Kledal, T.N.; Wills, M.R.; Rosenkilde, M.M. Distinct Roles of Extracellular Domains in the Epstein-Barr Virus-Encoded BILF1 Receptor for Signaling and Major Histocompatibility Complex Class I Downregulation. mBio 2019, 10, e01707-18. [CrossRef]

143. Vischer, H.F.; Nijmeijer, S.; Smit, M.J.; Leurs, R. Viral hijacking of human receptors through heterodimerization. Biochem. Biophys. Res. Commun. 2008, 377, 93-97. [CrossRef]

144. Nijmeijer, S.; Leurs, R.; Smit, M.J.; Vischer, H.F. The Epstein-Barr Virus-encoded G Protein-coupled Receptor BILF1 Heterooligomerizes with Human CXCR4, Scavenges G $\alpha$ i Proteins, and Constitutively Impairs CXCR4 Functioning. J. Biol. Chem. 2010, 285, 29632-29641. [CrossRef] [PubMed]

145. Paydas, S.; Ergin, M.; Erdogan, S.; Seydaoglu, G. Prognostic significance of EBV-LMP1 and VEGF-A expressions in non-Hodgkin's lymphomas. Leuk. Res. 2008, 32, 1424-1430. [CrossRef] [PubMed]

146. Krishna, S.M.; James, S.; Balaram, P. Expression of VEGF as prognosticator in primary nasopharyngeal cancer and its relation to EBV status. Virus Res. 2006, 115, 85-90. [CrossRef]

147. Hayes, S.H.; Seigel, G.M. Immunoreactivity of ICAM-1 in human tumors, metastases and normal tissues. Int. J. Clin. Exp. Pathol. 2009, 2, 553-560. [PubMed]

148. Lindberg, J.S.; Moe, S.M.; Goodman, W.G.; Coburn, J.W.; Sprague, S.M.; Liu, W.; Blaisdell, P.W.; Brenner, R.M.; Turner, S.A.; Martin, K.J. The calcimimetic AMG 073 reduces parathyroid hormone and calcium $x$ phosphorus in secondary hyperparathyroidism. Kidney Int. 2003, 63, 248-254. [CrossRef]

149. Ritter, K.; Buning, C.; Halland, N.; Pöverlein, C.; Schwink, L. G Protein-Coupled Receptor 119 (GPR119) Agonists for the Treatment of Diabetes: Recent Progress and Prevailing Challenges. J. Med. Chem. 2016, 59, 3579-3592. [CrossRef]

150. Irving, C.B.; Adams, C.E.; Lawrie, S. Haloperidol versus placebo for schizophrenia. In Cochrane Database of Systematic Reviews; Irving, C.B., Ed.; John Wiley \& Sons, Ltd.: Chichester, UK, 2006.

151. Brinkmann, V.; Davis, M.D.; Heise, C.E.; Albert, R.; Cottens, S.; Hof, R.; Bruns, C.; Prieschl, E.; Baumruker, T.; Hiestand, P.; et al. The Immune Modulator FTY720 Targets Sphingosine 1-Phosphate Receptors. J. Biol. Chem. 2002, 277, 21453-21457. [CrossRef] [PubMed]

152. Nieto Gutierrez, A.; Mcdonald, P.H. GPCRs: Emerging anti-cancer drug targets. Cell. Signal. 2017, 41, 65-74. [CrossRef]

153. Perez Almeria, C.V.; Setiawan, I.M.; Siderius, M.; Smit, M.J. G protein-coupled receptors as promising targets in cancer. Curr. Opin. Endocr. Metab. Res. 2021, 16, 119-127. [CrossRef]

154. Dorr, P.; Westby, M.; Dobbs, S.; Griffin, P.; Irvine, B.; Macartney, M.; Mori, J.; Rickett, G.; Smith-Burchnell, C.; Napier, C.; et al. Maraviroc (UK-427,857), a potent, orally bioavailable, and selective small-molecule inhibitor of chemokine receptor CCR5 with broad-spectrum anti-human immunodeficiency virus type 1 activity. Antimicrob. Agents Chemother. 2005, 49, 4721-4732. [CrossRef] [PubMed]

155. Heasley, L.E. Autocrine and paracrine signaling through neuropeptide receptors in human cancer. Oncogene 2001, 20, 1563-1569. [CrossRef] [PubMed]

156. Trejo, J. Dysregulation of G Protein-Coupled Receptor Signaling in Cancer. In Signal Transduction: Pathways, Mechanisms and Diseases; Springer: Berlin/Heidelberg, Germany, 2010; pp. 83-98, ISBN 9783642021114.

157. Kashyap, M.K.; Kumar, D.; Jones, H.; Amaya-Chanaga, C.I.; Choi, M.Y.; Melo-Cardenas, J.; Ale-Ali, A.; Kuhne, M.R.; Sabbatini, P.; Cohen, L.J.; et al. Ulocuplumab (BMS-936564/MDX1338): A fully human anti- CXCR4 antibody induces cell death in chronic lymphocytic leukemia mediated through a reactive oxygen speciesdependent pathway. Oncotarget 2016, 7, 2809-2822. [CrossRef] [PubMed]

158. Rosenkilde, M.M.; Kledal, T.N.; Bräuner-Osborne, H.; Schwartz, T.W. Agonists and Inverse Agonists for the Herpesvirus 8encoded Constitutively Active Seven-transmembrane Oncogene Product, ORF-74. J. Biol. Chem. 1999, 274, 956-961. [CrossRef] [PubMed]

159. Chatterjee, D.; Chandran, B.; Berger, E.A. Selective killing of Kaposi's sarcoma-associated herpesvirus lytically infected cells with a recombinant immunotoxin targeting the viral gpK8.1A envelope glycoprotein. $m A b s$ 2012, 4, 233-242. [CrossRef] [PubMed]

160. Cai, Y.; Berger, E.A. An immunotoxin targeting the gH glycoprotein of KSHV for selective killing of cells in the lytic phase of infection. Antivir. Res. 2011, 90, 143-150. [CrossRef]

161. Lee, S.; Chung, Y.H.; Lee, C. US28, a Virally-Encoded GPCR as an Antiviral Target for Human Cytomegalovirus Infection. Biomol. Ther. 2017, 25, 69-79. [CrossRef] 
162. Kralj, A.; Wetzel, A.; Mahmoudian, S.; Stamminger, T.; Tschammer, N.; Heinrich, M.R. Identification of novel allosteric modulators for the G-protein coupled US28 receptor of human cytomegalovirus. Bioorg. Med. Chem. Lett. 2011, 21, 5446-5450. [CrossRef]

163. Kralj, A.; Nguyen, M.T.; Tschammer, N.; Ocampo, N.; Gesiotto, Q.; Heinrich, M.R.; Phanstiel, O. Development of flavonoid-based inverse agonists of the key signaling receptor US28 of human cytomegalovirus. J. Med. Chem. 2013, 56, 5019-5032. [CrossRef] [PubMed]

164. Kralj, A.; Kurt, E.; Tschammer, N.; Heinrich, M.R. Synthesis and Biological Evaluation of Biphenyl Amides That Modulate the US28 Receptor. ChemMedChem 2014, 9, 151-168. [CrossRef]

165. Lückmann, M.; Amarandi, R.-M.; Papargyri, N.; Jakobsen, M.H.; Christiansen, E.; Jensen, L.J.; Pui, A.; Schwartz, T.W.; Rosenkilde, M.M.; Frimurer, T.M. Structure-based discovery of novel US28 small molecule ligands with different modes of action. Chem. Biol. Drug Des. 2017, 89, 289-296. [CrossRef]

166. Amărandi, R.-M.; Lückmann, M.; Melynis, M.; Jakobsen, M.H.; Fallah, Z.; Spiess, K.; Hjortø, G.M.; Pui, A.; Frimurer, T.M.; Rosenkilde, M.M. Ligand-selective small molecule modulators of the constitutively active vGPCR US28. Eur. J. Med. Chem. 2018, 155, 244-254. [CrossRef]

167. Heukers, R.; Fan, T.S.; de Wit, R.H.; van Senten, J.R.; De Groof, T.W.M.; Bebelman, M.P.; Lagerweij, T.; Vieira, J.; de Munnik, S.M.; Smits-de Vries, L.; et al. The constitutive activity of the virally encoded chemokine receptor US28 accelerates glioblastoma growth. Oncogene 2018, 37, 4110-4121. [CrossRef] [PubMed]

168. De Groof, T.W.M.; Mashayekhi, V.; Fan, T.S.; Bergkamp, N.D.; Sastre Toraño, J.; van Senten, J.R.; Heukers, R.; Smit, M.J.; Oliveira, S. Nanobody-Targeted Photodynamic Therapy Selectively Kills Viral GPCR-Expressing Glioblastoma Cells. Mol. Pharm. 2019, 16, 3145-3156. [CrossRef]

169. De Groof, T.; Elder, E.; Heukers, R.; Lim, E.; Wills, M.; Sinclair, J.; Smit, M. Targeting the latent human cytomegalovirus reservoir with virus specific nanobodies. bioRxiv 2020. [CrossRef]

170. Spiess, K.; Jeppesen, M.G.; Malmgaard-Clausen, M.; Krzywkowski, K.; Dulal, K.; Cheng, T.; Hjortø, G.M.; Larsen, O.; Burg, J.S.; Jarvis, M.A.; et al. Rationally designed chemokine-based toxin targeting the viral G protein-coupled receptor US28 potently inhibits cytomegalovirus infection in vivo. Proc. Natl. Acad. Sci. USA 2015, 112, 8427-8432. [CrossRef]

171. Krishna, B.A.; Spiess, K.; Poole, E.L.; Lau, B.; Voigt, S.; Kledal, T.N.; Rosenkilde, M.M.; Sinclair, J.H. Targeting the latent cytomegalovirus reservoir with an antiviral fusion toxin protein. Nat. Commun. 2017, 8, 14321. [CrossRef] [PubMed]

172. Spiess, K.; Jeppesen, M.G.; Malmgaard-Clausen, M.; Krzywkowski, K.; Kledal, T.N.; Rosenkilde, M.M. Novel Chemokine-Based Immunotoxins for Potent and Selective Targeting of Cytomegalovirus Infected Cells. J. Immunol. Res. 2017, 2017, 1-12. [CrossRef] [PubMed]

173. Chen, R.; Zhang, D.; Mao, Y.; Zhu, J.; Ming, H.; Wen, J.; Ma, J.; Cao, Q.; Lin, H.; Tang, Q.; et al. A Human Fab-Based Immunoconjugate Specific for the LMP1 Extracellular Domain Inhibits Nasopharyngeal Carcinoma Growth In Vitro and In Vivo. Mol. Cancer Ther. 2012, 11, 594-603. [CrossRef]

174. Zhu, S.; Chen, J.; Xiong, Y.; Kamara, S.; Gu, M.; Tang, W.; Chen, S.; Dong, H.; Xue, X.; Zheng, Z.-M.; et al. Novel EBV LMP-2affibody and affitoxin in molecular imaging and targeted therapy of nasopharyngeal carcinoma. PLoS Pathog. 2020, 16, e1008223. [CrossRef] [PubMed] 